\title{
Petrography and geochemistry of Jurassic sandstones from the Jhuran Formation of Jara dome, Kachchh basin, India: Implications for provenance and tectonic setting
}

\author{
V Periasamy $^{1,2}$ and M Venkateshwarlu ${ }^{1, *}$ \\ ${ }^{1}$ CSIR-National Geophysical Research Institute, Uppal Road, Hyderabad 500 007, India. \\ ${ }^{2}$ Present Address: Geologist, Geological Survey of India, Bandlaguda, Hyderabad 500 068, India. \\ ${ }^{*}$ Corresponding author.e-mail: mamila_v@rediffmail.com
}

Sandstones of Jhuran Formation from Jara dome, western Kachchh, Gujarat, India were studied for major, trace and rare earth element (REE) geochemistry to deduce their paleo-weathering, tectonic setting, source rock characteristics and provenance. Petrographic analysis shows that sandstones are having quartz grains with minor amount of $\mathrm{K}$-feldspar and lithic fragments in the modal ratio of $\mathrm{Q}_{89}: \mathrm{F}_{7}: \mathrm{L}_{4}$. On the basis of geochemical results, sandstones are classified into arkose, sub-litharenite, wacke and quartz arenite. The corrected CIA values indicate that the weathering at source region was moderate to intense. The distribution of major and REE elements in the samples normalized to upper continental crust (UCC) and chondrite values indicate similar pattern of UCC. The tectonic discrimination diagram based on the elemental concentrations and elemental ratios of $\mathrm{Fe}_{2} \mathrm{O}_{3}+\mathrm{MgO}$ vs. $\mathrm{TiO}_{2}, \mathrm{SiO}_{2}$ vs. $\log \left(\mathrm{K}_{2} \mathrm{O} / \mathrm{Na}_{2} \mathrm{O}\right), \mathrm{Sc} / \mathrm{Cr}$ vs. La/Y, Th-Sc-Zr/10, La-Th-Sc plots Jhuran Formation samples in continental rift and collision settings. The plots of $\mathrm{Ni}$ against $\mathrm{TiO}_{2}, \mathrm{La} / \mathrm{Sc}$ vs. Th/Co and $\mathrm{V}-\mathrm{Ni}-\mathrm{Th} * 10$ reveals that the sediments of Jhuran Formation were derived from felsic rock sources. Additionally, the diagram of $(\mathrm{Gd} / \mathrm{Yb})_{\mathrm{N}}$ against $\mathrm{Eu} / \mathrm{Eu}^{*}$ suggest the post-Archean provenance as source possibly Nagar Parkar complex for the studied samples.

\section{Introduction}

The chemical composition of terrigenous sedimentary rocks can be studied to understand the tectonic setting, weathering, source rock compositions, provenance and diagenesis (Nesbitt and Young 1982; Bhatia 1983; Roser and Korsch 1986; McLennan 1989; Condie 1993; Cullers 1995). Traditional petrographic analyses reveal the processes associated with provenance, environment of deposition and transportation of clastic materials (Dickinson and Suczek 1979; Ingersoll and Suczek 1979; Dickinson 1985). However, the framework grains of sandstone are liable to be modified under burial and compaction which can mislead the conclusions.
Whereas, the precision of geochemical data enable researchers to understand in detail the information contained in clastic sedimentary rocks (McLennan et al. 1993; Kroonenberg 1994; Armstrong-Altrin et al. 2004). In addition, the distribution of major elements in sandstone provides more insight details on tectonic setting in terms of discrimination diagrams as long as the bulk chemical composition of a rock is not altered (Bhatia 1983; Roser and Korsch 1986; McLennan 1989; Nesbitt and Young 1989). Also, the trace and rare earth element (REE) composition of sandstone can reflect the provenance and tectonic settings of sedimentary basin due to their immobility during weathering and transportation processes and relatively short residence

Keywords. Petrography; trace and REE geochemistry; Jara dome; Jhuran Formation; Kachchh basin. 
time in sea water (Holland 1978; McLennan et al. 1983; Armstrong-Altrin and Verma 2005; Verma and Armstrong-Altrin 2013).

Kachchh sedimentary basin is a peri-cratonic and paleo rift basin in the western margin of India, where the development of sediments during Jurassic period is well known (Biswas 1987). The eastwest trending basin is southernmost end of Indus shelf, bordered on north by fossil rift of Thar and southern Indus basin and in south by Narmada rift (Zaigham and Mallick 2000; Biswas 2005). The well exposed outcrops of sedimentary rocks in Kachchh basin has received significant attention from several authors in all aspects of paleontological, structural, stratigraphical and hydrocarbon prospects for many decades (Waagen 1873; Biswas 1987; Biswas and Deshpande 1983; Krishna 1987; Bhawani Singh et al. 2008). However, many lithocolumns of this basin remained untouched in terms of geochemical study. The aim of this study is to integrate petrography, major, trace and REE results to assess: (1) the source rock identification and its implications for provenance, (2) to evaluate the weathering intensity and (3) to study the tectonic setting of the region.

\section{Geological setting}

Kachchh basin is situated in the state of Gujarat, western India in between the lat. $22^{\circ} 30^{\prime}-24^{\circ} 30^{\prime} \mathrm{N}$ and long. $68^{\circ}-72^{\circ} \mathrm{E}$ (figure 1). The basin was formed as a consequence of the break-up of eastern part of the western Gondwanaland during late Triassic/Early Jurassic period (Norton and Sclater 1979). It is bounded by Nagar Parkar Fault (NPF) block and North Kathiawar Fault (NKF) block on northern and southern rifts, respectively. The rift basin contains several intra-basinal strike faults trending in east-west direction, resulted in a series of half-grabens. The main strike faults in the basin, such as the Island Belt Fault (IBF), the Banni Fault (BF), the Kachchh Mainland Fault (KMF), the Katrol Hill Fault (KHF) and South Wagad Fault (SWF) have the uplifted footwalls exposed as excellent outcrop areas and half-grabens to form as an extensive plain covered by recent sediments (Biswas 2005). The unique feature of this rift basin is the occurrence of the first order meridional (NNE-SSW) high across the middle of the basin (Biswas 1987).

The basin consists of 2000-3000-m thick Mesozoic sediments ranging in age from Middle Jurassic to Lower Cretaceous, $600 \mathrm{~m}$ of Tertiary sediments and thin sheet of Quaternary sediments deposited in different rift stages of the basin. The major outcrop areas occurred in several uplifted regions of the basin such as Kachchh Mainland, Pachham Island, Khadir Island, Bela Island, Chorar Island and Wagad uplifts (figure 1), which are separated by vast plains of the Great and Little Ranns and

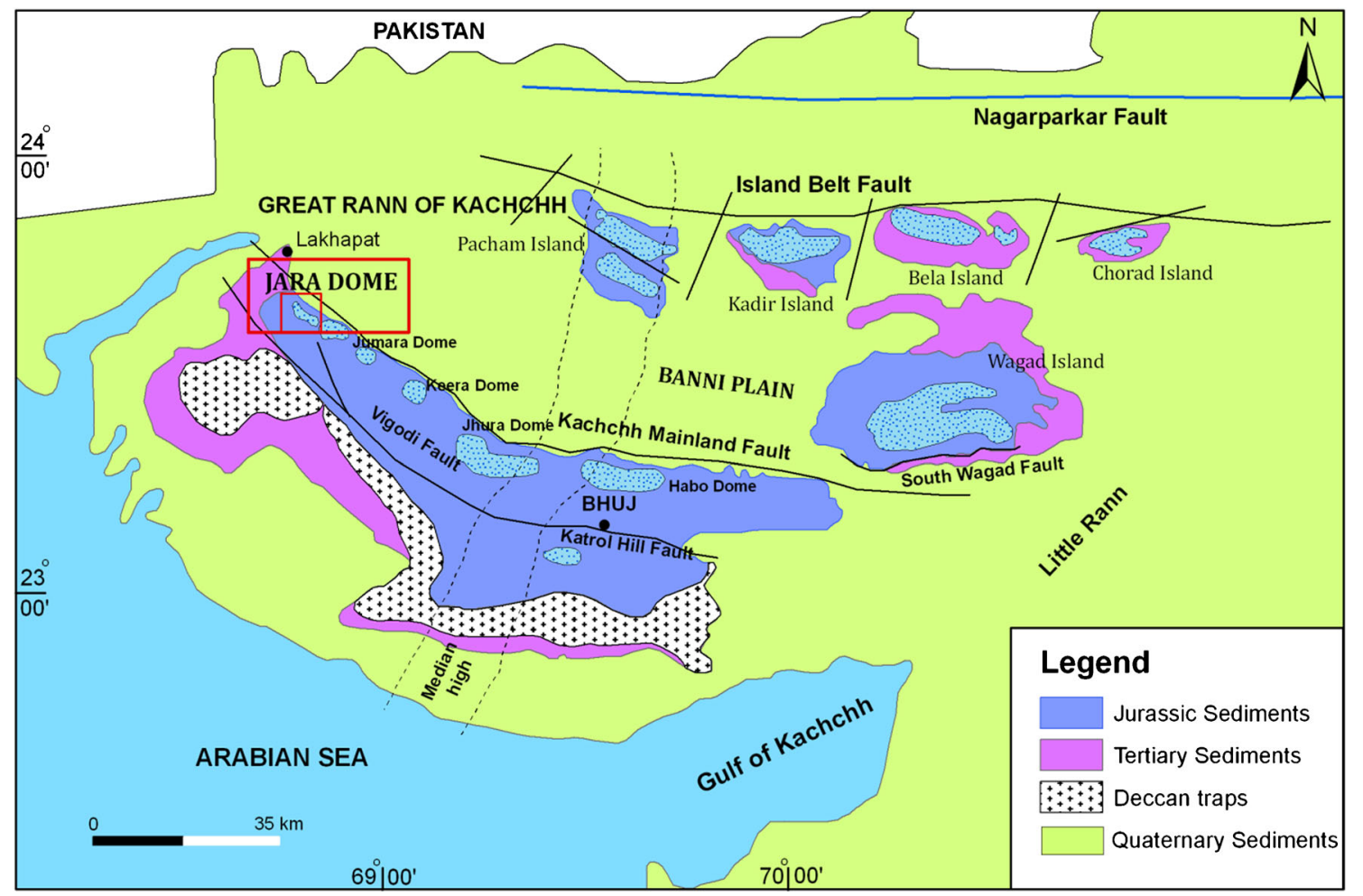

Figure 1. Generalised geological map of the Kachchh basin, western India (modified after Wynne 1872) showing the study area in red box. 
Banni plains occupied by alluvial sediments and salt pan (Biswas 1977).

The lithostratigraphy of the Kachchh basin is chiefly controlled by fault-bounded regions; however, the development of rock sequences from middle Jurassic to lower Cretaceous is well preserved in Kachchh Mainland. The stratigraphic succession of Kachchh Mainland is divided into four formations named as Jhurio (BathonianCallovian), Jumara (Callovian-Oxfordian), Jhuran (Kimmeridgian-Lower Cretaceous) and Bhuj (pre-Aptian-Santonian(?)) formations in ascending stratigraphic order (Biswas 1977), which are best exposed in a series of domes at Habo, Jhura, Keera, Nara, Jumara and Jara hills (figure 1). The lithological sequence of these formations consists of clastic sandstone, siltstone, shale and limestone with distinct demarcation boundary, deposited in marine to fluvio-deltaic conditions. The present study was focussed on the Jhuran Formation of Upper Jurassic period (Kimmeridgian-Tithonian) in and around Jara dome since the greatest thickness of the sediments is preserved and exposed here.

Jara dome is located in western fringe of the Mainland Kachchh where the Jumara, Jhuran and Bhuj formations are best exposed (figure 1). The stratigraphic sequence of the Jhuran Formation in Jara dome contains alternating beds of sandstone and shale (figure 2) deposited from Kimmeridgian to Tithonian period overlies the Jumara formation (Biswas 1977; Kanjilal and Prasad 1992). The sequences of the Jhuran Formation commence with Rudramata shale, Katasar member followed
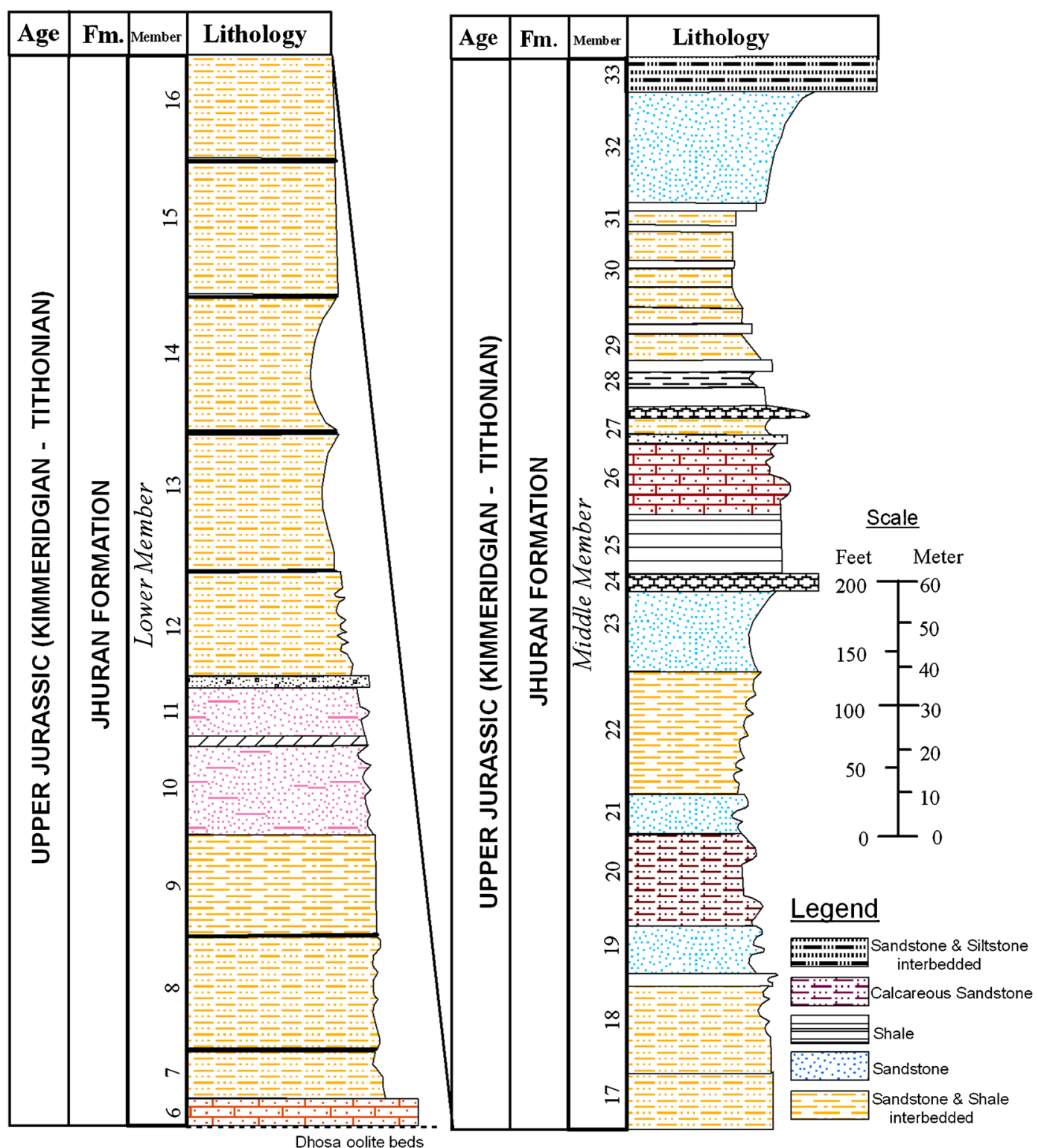

Figure 2. Lithostratigraphic column of the Jhuran Formation, Jara dome showing the sampling locations in numbers. 
by Upper member are well exposed around Jara dome and Lakhapar section (Biswas 1977). The lower boundary of the formation is demarcated by Dhosa Oolite bed of the Jumara Formation and the upper by distinct lithological variation. The studied section is located around lat. $23^{\circ} 43^{\prime} 96^{\prime \prime} \mathrm{N}$ and long. $68^{\circ} 56^{\prime} 17^{\prime \prime} \mathrm{E}$ composed of $\sim 500-\mathrm{m}$ thick sediments belonging to lower and middle members of the Jhuran Formation. The lithology of lower member beds consists of repetitive siliceous and thin calcareous sandstones with shale interbedded and the middle member is characterized by alternations of dark grey to light grey shales and calcareous, flaggy, whitish to yellowish siltstone bands.

\section{Materials and methods}

A total of 50 samples were collected from the outcrops of lower and middle members of the Jhuran Formation from Jara dome of western Kachchh basin (figure 2). We prepared 25 thin sections representing entire $\sim 500$-m thick litho column and all were subjected to detailed petrographic analysis with optical microscopy. Four hundred points were counted on 20 clastic sandstone samples using conventional point counting method following the method given by Dickinson and Suczek (1979) and Dickinson et al. (1983). The XRD analyses were performed on arkose, sub-litharenite, wacke and quartz arenite samples using Bruker D-8 Advance power XRD available at CSIR-Indian Institute of Chemical Technology, Hyderabad.

Major oxide concentrations were determined using X-ray fluorescence (XRF) spectrometry. For this experiment, 30 fresh sandstone rock samples were selected and washed thoroughly with distilled water. Samples were powdered individually on agate mortar to prevent from contamination and made pellets using backing of boric acid in collapsible aluminum cups and pressing at 20 tons of pressure by hydraulic press. A Philips MagiX PRO Model PW 2440 X-ray fluorescence spectrometer coupled with an automatic sample changer PW 2540 available at CSIR-National Geophysical Research Institute (NGRI), India was used to determine the major oxides in the sandstone samples. The standard GSR4 was used for calibration and to check the accuracy of XRF instrument for major oxide analysis. The precision of the chemical analysis is better than $10 \%$ which is observed from replicate analysis of samples and standard. Loss on ignition (LOI) was determined by weighing $1 \mathrm{~g}$ of dried samples before and after heating at $1000^{\circ} \mathrm{C}$ for $1.5 \mathrm{hrs}$.

Trace-element and REE geochemistry analysis were performed for 20 representative samples by inductively coupled plasma mass spectrometer
(ICP-MS) available at CSIR-NGRI, India. The sample solutions were prepared following the inhouse standard method developed by Parijat Roy et al. (2007). A Perkin Elmer SCIEX, Model ELAN ${ }^{\circledR}$ DRC II ICP-mass spectrometer (Toronto, ON, Canada) was used in this study, the instrument was calibrated with the standard GSR4. The analytical precision for trace elements and REEs is generally better than $5 \%$.

\section{Results}

\subsection{Sandstone petrography}

The petrographic analysis revealed that the sandstones from the Jhuran Formation are characterized by fine-to-coarse grained sandstone with fair amount

Table 1. Modal analysis data (in \%) for Jhuran Formation from Jara dome, Kachchh basin.

\begin{tabular}{|c|c|c|c|c|c|c|c|c|}
\hline Sample ID & $\mathrm{Qm}$ & $\mathrm{Qp}$ & K & $\mathrm{P}$ & $\mathrm{L}$ & $\begin{array}{c}\mathrm{Q} \\
(\%)\end{array}$ & $\begin{array}{c}\mathrm{F} \\
(\%)\end{array}$ & $\begin{array}{c}\mathrm{L} \\
(\%)\end{array}$ \\
\hline JA01 & 81 & 2 & 12 & 3 & 2 & 83 & 15 & 2 \\
\hline JA02 & 80 & 2 & 13 & 2 & 3 & 82 & 15 & 3 \\
\hline JA03 & 82 & 3 & 10 & 3 & 2 & 85 & 13 & 2 \\
\hline JA05 & 83 & 4 & 8 & 3 & 2 & 87 & 11 & 2 \\
\hline JA06 & 85 & 2 & 7 & 3 & 3 & 87 & 10 & 3 \\
\hline JA07 & 81 & 2 & 12 & 2 & 3 & 83 & 14 & 3 \\
\hline JA08 & 84 & 3 & 9 & 2 & 2 & 87 & 11 & 2 \\
\hline JA11 & 83 & 3 & 10 & 2 & 2 & 86 & 12 & 2 \\
\hline JA04 & 85 & 2 & 8 & 2 & 3 & 87 & 10 & 3 \\
\hline JA10 & 84 & 2 & 8 & 2 & 4 & 86 & 10 & 4 \\
\hline JA12 & 86 & 3 & 6 & 2 & 3 & 89 & 8 & 3 \\
\hline JA15 & 80 & 5 & 7 & 3 & 5 & 85 & 10 & 5 \\
\hline JA29 & 83 & 4 & 9 & 2 & 2 & 87 & 11 & 2 \\
\hline JA30 & 86 & 2 & 5 & 3 & 4 & 88 & 8 & 4 \\
\hline JA09 & 84 & 3 & 8 & 3 & 2 & 87 & 11 & 2 \\
\hline JA16 & 85 & 2 & 5 & 2 & 6 & 87 & 7 & 6 \\
\hline JA17 & 81 & 2 & 7 & 4 & 6 & 83 & 11 & 6 \\
\hline JA18 & 84 & 2 & 8 & 2 & 4 & 86 & 10 & 4 \\
\hline JA19 & 79 & 3 & 8 & 3 & 7 & 82 & 11 & 7 \\
\hline JA14 & 84 & 2 & 6 & 2 & 6 & 86 & 8 & 6 \\
\hline JA26 & 83 & 3 & 7 & 2 & 5 & 86 & 9 & 5 \\
\hline JA13 & 87 & 3 & 6 & 2 & 2 & 90 & 8 & 2 \\
\hline JA20 & 84 & 4 & 8 & 2 & 2 & 88 & 10 & 2 \\
\hline JA21 & 83 & 5 & 7 & 2 & 3 & 88 & 9 & 3 \\
\hline JA22 & 83 & 5 & 7 & 2 & 3 & 88 & 9 & 3 \\
\hline JA23 & 88 & 3 & 6 & 1 & 2 & 91 & 7 & 2 \\
\hline JA24 & 89 & 3 & 5 & 1 & 2 & 92 & 6 & 2 \\
\hline JA25 & 89 & 2 & 4 & 2 & 3 & 91 & 6 & 3 \\
\hline JA 27 & 83 & 4 & 7 & 2 & 4 & 87 & 9 & 4 \\
\hline JA28 & 91 & 2 & 3 & 2 & 2 & 93 & 5 & 2 \\
\hline
\end{tabular}

$\mathrm{Q}=$ total quartz, $\mathrm{Qm}=$ monocrystalline quartz grains, $\mathrm{Qp}=$ polycrystalline quartz grains, $\mathrm{K}=$ potash feldspar, $\mathrm{P}=$ plagioclase, $\mathrm{L}$ (lithic fragments) $=\mathrm{Lv}$ (volcanic lithic fragments) + Ls (sedimentary lithic fragments) + Lm (metamorphic lithic fragments). 
of matrix. Point counting study was performed on 20 representative thin sections from the studied area (table 1). The microphotographs of sandstones of the Jhuran Formation, Jara dome are shown in figure 3. The framework grains of Jhuran sandstones are made of monocrystalline quartz
(Qn), polycrystalline quartz (Qp), undulatory monocrystalline quartz $(\mathrm{Qu})$, K-feldspar, plagioclase and lithic fragments. Quartz is subrounded to subangular with mechanical fractures and on an average, monocrystalline quartz (87\%) dominates over polycrystalline quartz (1.62\%)
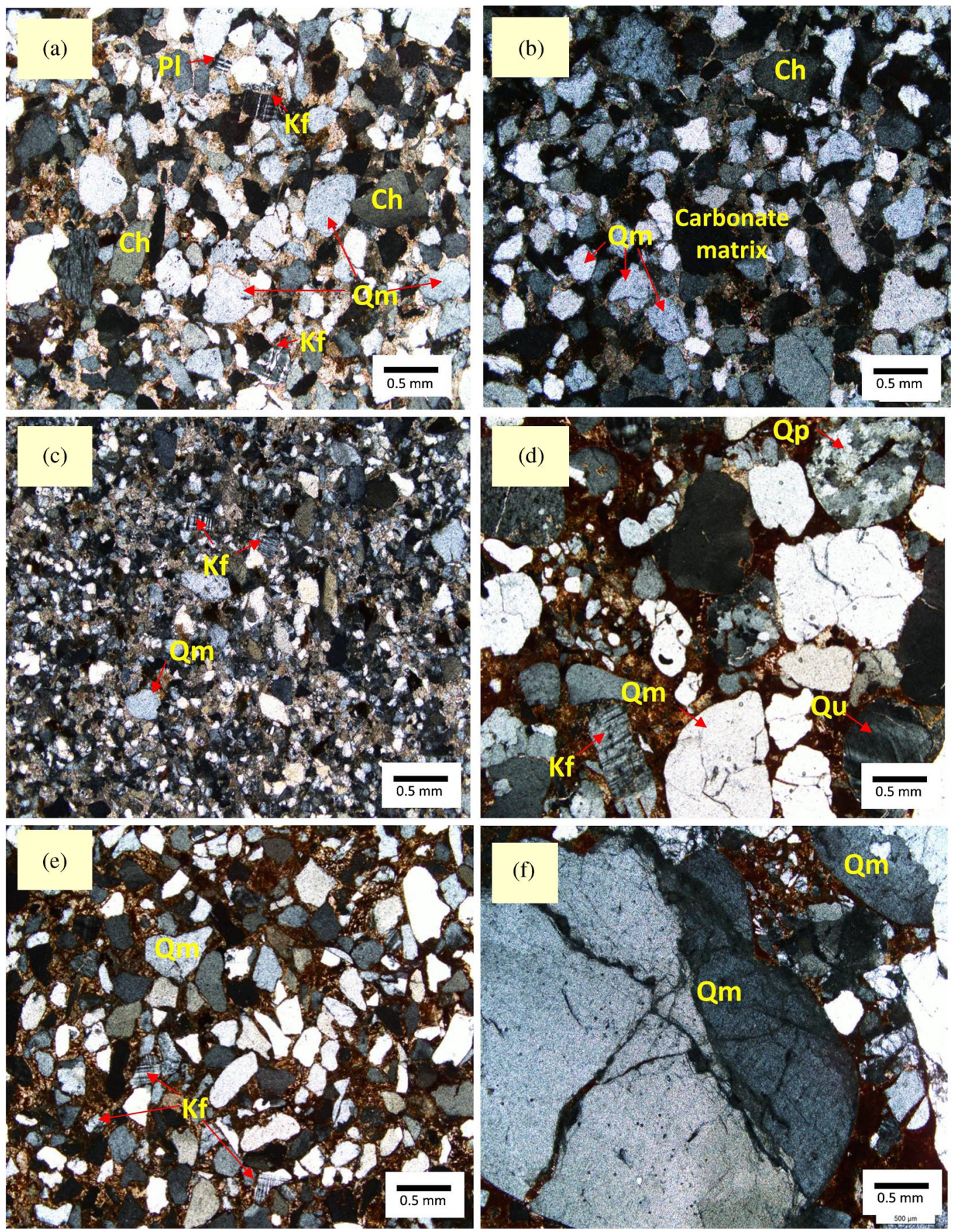

Figure 3. Microphotographs of sandstones from the Jhuran Formation. (a) Arkosic sandstone with subrounded monocrystalline quartz $(\mathrm{Qm})$, K-felspar (Kf), plagioclase $(\mathrm{Pl})$ and chert $(\mathrm{Ch})$ minerals cemented by carbonate matrix. (b) Arkose sandstone contains largely of monocrystalline quartz $(\mathrm{Qm})$, chert $(\mathrm{Ch})$ and carbonate cement. (c) Wacke sandstone shows fresh K-felspar (Kf) and fine grained monocrystalline quartz (Qm). (d) Quartz arenite with monocrystalline quartz (Qm), polycrystalline quartz $(\mathrm{Qp})$, undulose quartz $(\mathrm{Qu})$, K-felspar $(\mathrm{Kf})$ and iron cement. (e) Quartz arenite shows subrounded monocrystalline quartz (Qm) and fresh K-felspar (Kf). (f) Quartz arenite with large size grains of monocrystalline quartz (Qm) shows mechanical fracture. 


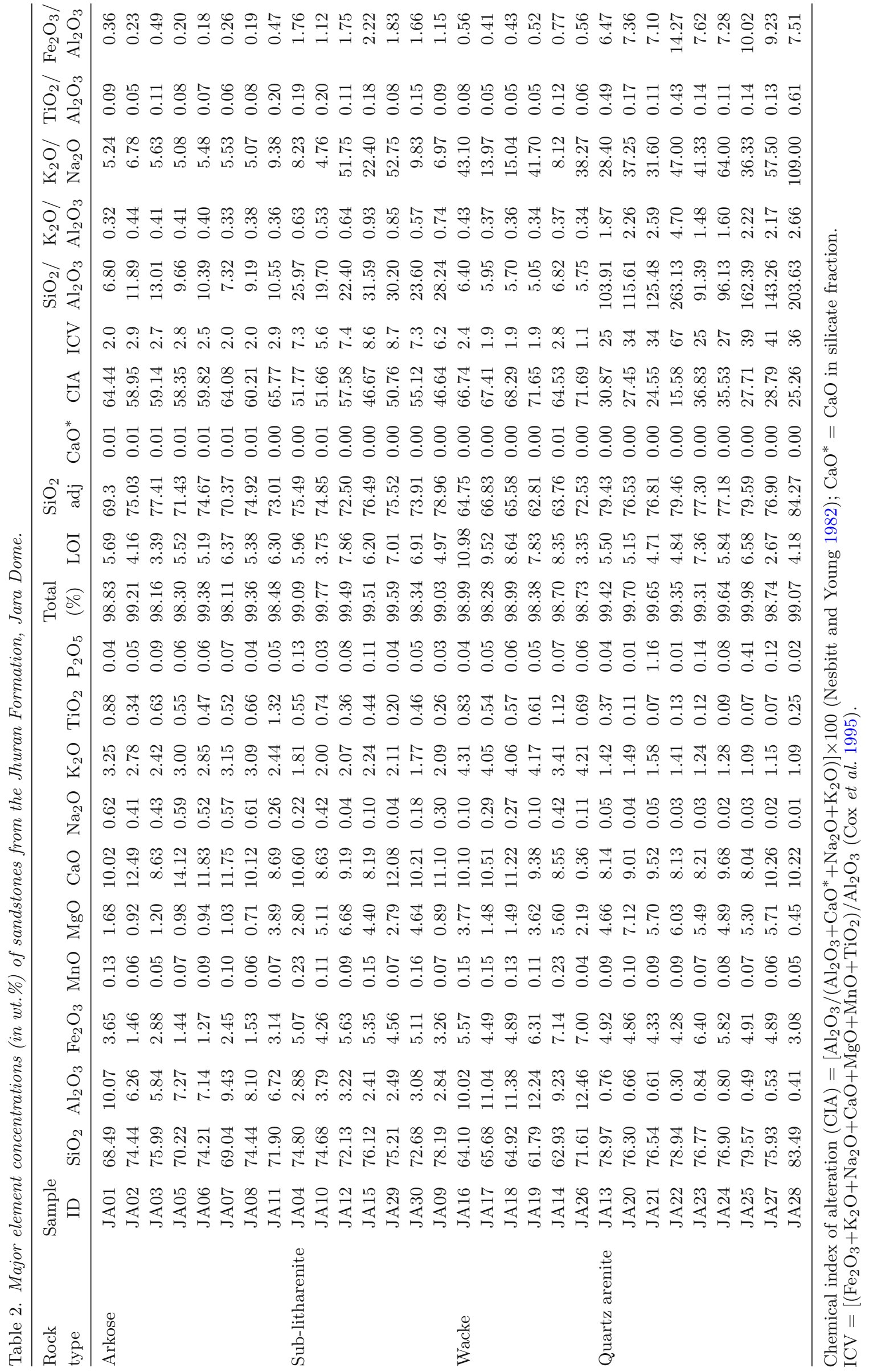


(figure 3a). Subrounded-to-subangular feldspars (both plagioclase and K-feldspar) are present in considerable amount, but K-felspar especially microcline (4.5\%) is higher (figure 3a). K-feldspars in Jhuran sandstones are fresh with cross-hatched twinning (microcline) and the plagioclase shows polysynthetic twinning. On an average, lithic fragments in the samples comprise of $2.7 \%$ of the modal percentage. Among the lithic fragments, sedimentary lithics especially chert are common (figure 3a, b). The sandstones of the Jhuran Formation are cemented with both calcareous and ferruginous matrices with the amount varying from 2 to $15 \%$ (figure $3 \mathrm{c}, \mathrm{d}$ and e). The quartz grains vary in size largely and show mechanical fractures due to compaction (figure 3f). The average modal percentage of quartz, feldspar and lithic fragments from all the studied samples are 89,7 , and $4 \%$, respectively. The XRD result shows that the d spacing Á equivalent values of zircons apart from quartz, orthoclase, microcline, ilmenite and few clay minerals.

\section{Geochemistry}

\subsection{Major elements}

The major oxide concentration of the Jhuran Formation from Jara dome is presented in table 2 . The sandstones from the Jhuran Formation are classified into arkose, sub-litharenite, wacke and quartz arenite based on geochemical characteristics after Herron (1988). Figure 4 shows the geochemical classification of sandstone samples from the Jhuran Formation. The sandstones of all types from the Jhuran Formation shows relatively high $\mathrm{SiO}_{2}$ content with minor variation among arkose (72\%), sub-litharenite $(74 \%)$ and wacke $(65 \%)$, while slight enrichment of $\mathrm{SiO}_{2}$ (wt\%) in quartz arenite (78 wt\%) is observed as a consequence of higher quantity of quartz. Except quartz arenite all other sandstone types show related $\mathrm{Al}_{2} \mathrm{O}_{3}(5.11 \%)$ content, the depletion of $\mathrm{Al}_{2} \mathrm{O}_{3}$ in quartz arenite $(0.6 \%)$ can be attributed to the larger amount of detrital quartz grains in this sandstone which is consistent with petrographic evidence. The $\mathrm{Na}_{2} \mathrm{O}$ concentration in arkose is $0.26-0.62 \%$, sub-litharenite (0.04$0.42 \%)$, wacke $(0.10-0.42 \%)$ and quartz arenite (0.01-0.05\%). Sandstones show depleted nature. All sandstone samples from the Jhuran Formation are enriched with $\mathrm{K}_{2} \mathrm{O}$ content in arkose (2.42$3.25 \mathrm{wt} \%)$, sub-litharenite $(1.77-2.24 \mathrm{wt} \%)$, wacke (3.41-4.31 wt\%) and quartz arenite (0.09-1.58 wt\%) proves the dominance of K-rich feldspar in their mineral composition. However, slight depletion is observed in quartz arenite, which is consistent with petrographic analysis. In addition, the ratio of $\mathrm{K}_{2} \mathrm{O} / \mathrm{Na}_{2} \mathrm{O}$ for all sandstone types is $27.25 \%$, which is $>1$, strongly support the dominance of K-rich feldspar content. The average concentrations of $\mathrm{MgO}$ and $\mathrm{MnO}$ among all sandstones are 3.41 and $0.1 \%$, respectively (table 2 ).

Figure 5 is the Harker variation diagram of $\mathrm{Al}_{2} \mathrm{O}_{3}$ vs. selected major oxides of sandstones from the Jhuran Formation. In Harker diagram, $\mathrm{Al}_{2} \mathrm{O}_{3}$

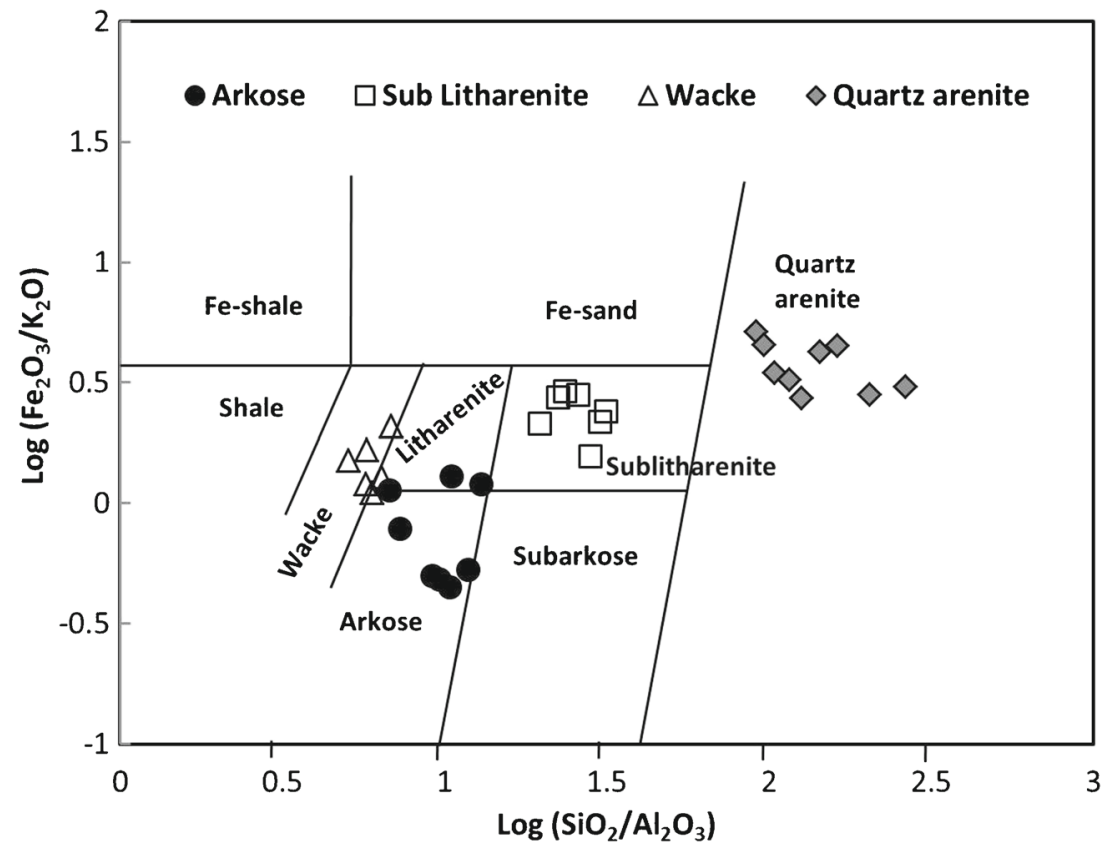

Figure 4. Geochemical classification diagram of sandstone samples from the Jhuran Formation based on $\log \left(\mathrm{SiO}_{2} / \mathrm{Al}_{2} \mathrm{O}_{3}\right)-$ $\log \left(\mathrm{Fe}_{2} \mathrm{O}_{3} / \mathrm{K}_{2} \mathrm{O}\right)$ (after Herron 1988). 

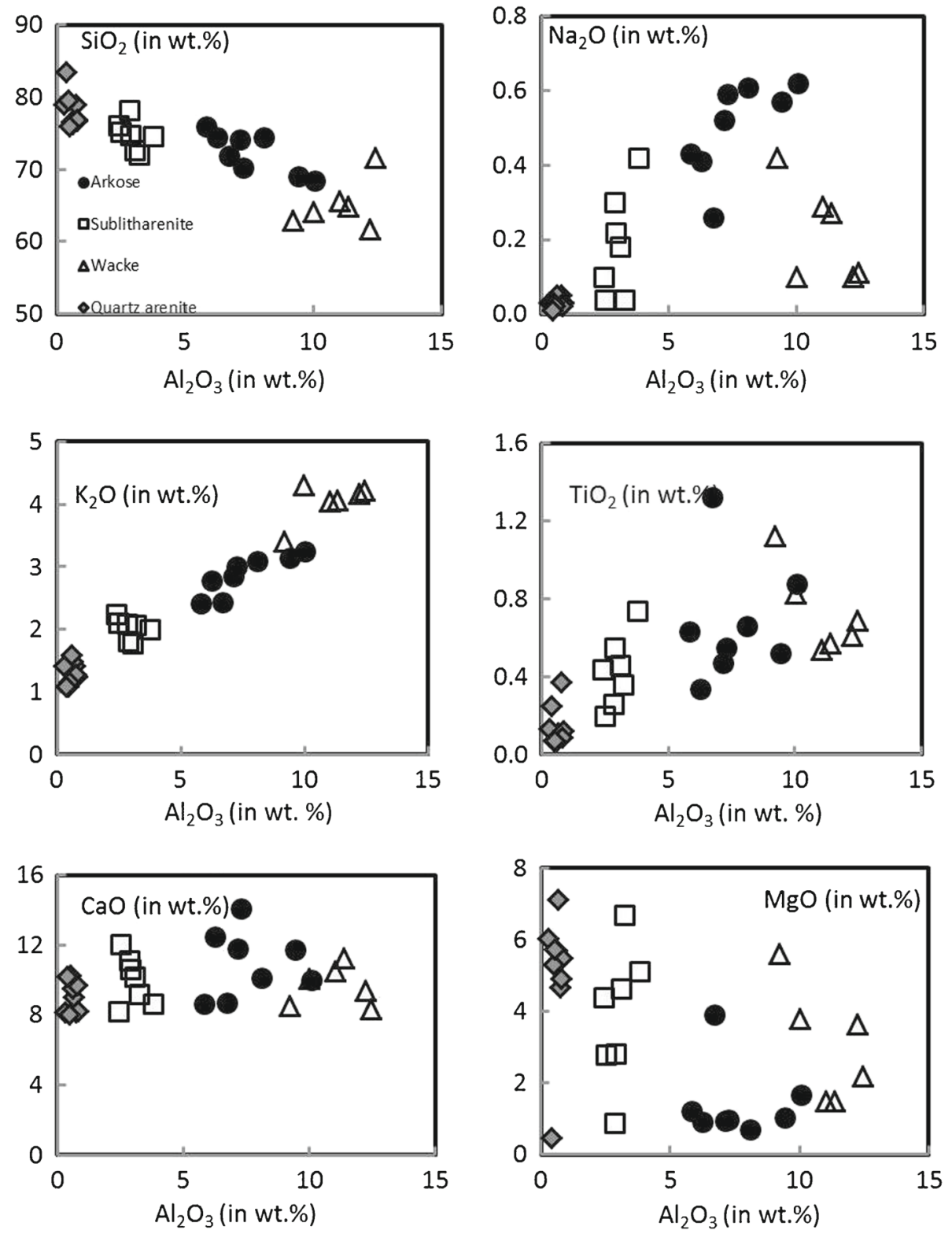

Figure 5. Harker variation diagram of $\mathrm{Al}_{2} \mathrm{O}_{3}$ vs. selected major oxides of sandstones from the Jhuran Formation.

against $\mathrm{SiO}_{2}$ demonstrates negative and positive correlations with $\mathrm{Na}_{2} \mathrm{O}, \mathrm{K}_{2} \mathrm{O}, \mathrm{TiO}_{2}$ and $\mathrm{MgO}$ indicates the mineral maturity in studied rocks (figure 6). All sandstone types from the Jhuran Formation are normalized to UCC (Taylor and McLennan 1985) and shown in figure 6(a). The plotted major oxides show flat trend to UCC except $\mathrm{Al}_{2} \mathrm{O}_{3}$ and $\mathrm{Na}_{2} \mathrm{O}$, which show moderate to strong depletions especially in quartz arenite samples (figure 6a). The enrichment of $\mathrm{MgO}$ can be attributed to the association with phyllosilicates input, whereas depletion of $\mathrm{Al}_{2} \mathrm{O}_{3}$ and $\mathrm{Na}_{2} \mathrm{O}$ can be associated with nonphyllosilicate in the sediments. All the samples have relatively high LOI caused by elevated concentration of $\mathrm{CaO}$ in the studied samples.

\subsection{Trace elements}

Trace element concentrations of sandstone samples from the Jhuran Formation are analysed and presented in table 3 . The distribution of trace elements in all the analyzed sandstone samples display relatively similar pattern normalized to UCC with depletion and enrichment of certain elements (figure 6b). The large-ion lithophile elements (LILE) such as $\mathrm{Rb}, \mathrm{Sr}, \mathrm{Cs}, \mathrm{Ba}, \mathrm{Th}$, and $\mathrm{U}$ are compared with UCC in which the Rb (16.7-86.8 ppm, $n=20)$, Sr (44.6-222 ppm, $n=20)$ and Cs (0.27-2.6 ppm, $n=20)$ are slightly depleted in all sandstone types with minor enrichment of $\mathrm{Th}$ $(1.83-66.6 \mathrm{ppm})$ and $\mathrm{U}(0.64-5.21 \mathrm{ppm})$ in wacke sandstone (figure $6 \mathrm{~b})$. The $\mathrm{Ba}(180-896 \mathrm{ppm})$ and 

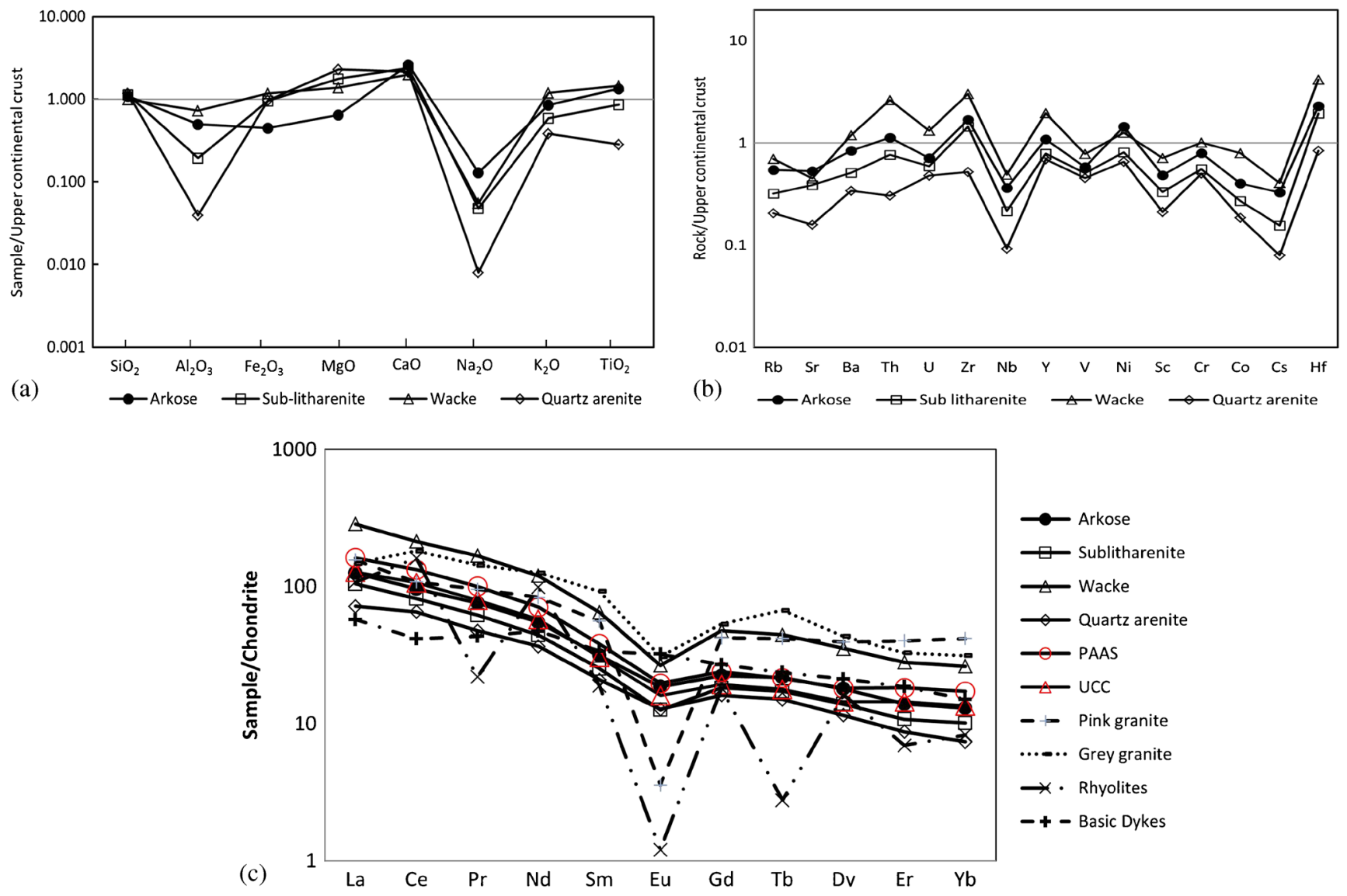

Figure 6. Plot of upper continental crust pattern for (a) major oxides, (b) trace elements and (c) chondrite-normalized average REE from Jhuran Formation. The values of Taylor and McLennan (1985) were used for UCC and chondrite normalization.

Cs $(0.27-2.6 \mathrm{ppm})$ concentrations in the Jhuran sandstones are lower than in UCC, while wacke sandstone slightly enriched with $\mathrm{Ba}$. The ratios of $\mathrm{Rb} / \mathrm{Sr}$ and $\mathrm{Th} / \mathrm{U}$ in analyzed samples ranging from $0.16-0.58$ and $0.94-12.78$, respectively (table 3 ). All the LILE, i.e., Rb, Sr, Cs, Ba, Th and U are showing high positive correlation coefficient $(r=$ $0.98,0.59,0.86,0.96,0.47$ and 0.55 , respectively) with $\mathrm{Al}_{2} \mathrm{O}_{3}$ which implies that their distributions in the Jhuran sandstones is predominantly controlled by phyllosilicates (suggested by McLennan et al. 1983).

The concentrations of $\mathrm{Zr}$, Hf, $\mathrm{Y}$ and $\mathrm{Nb}$ (highfield strength elements, HFSE) are relatively similar to those of UCC. Among HFSE, Zr (avg. = $407 \mathrm{ppm})$ and Hf (avg. = $723 \mathrm{ppm}$ ) are enriched in arkose, sub-litharenite and wacke sandstones, respectively and depleted in quartz arenite (figure 6b) due to their strong affinity with finegrained sediments (mostly clays) by grain size fractionation process. All the samples show low $\mathrm{Nb}$ (1.4-15.5 ppm) content than in UCC. Overall ratio of $\mathrm{Zr} / \mathrm{Hf}$ ranges from 16.7 to 34.3 (table 3), which suggests the presence of heavy minerals in the studied samples. The correlation coefficient of $\mathrm{Zr}$ with Hf is 0.99 , which is matching with the value obtained by Murali et al. (1983) suggests that these elements are primarily controlled by zircon.

The distribution of transition trace elements (TTE) Cr, Ni, Sc, Cu, and V in Jhuran sandstones show slight depletion as comparable to UCC (figure 6b), which can be attributed to low basic rock in the source area. In TTE, the Sc (1.5-8.4 $\mathrm{ppm}$ ) content is lower in all sandstones, whereas other elements are similar to those in UCC. The $\mathrm{Cr}$ concentration in the samples varies from 13.3 to $46.3 \mathrm{ppm}$ and show strong positive correlation coefficient with $\mathrm{Al}_{2} \mathrm{O}_{3}(r=0.85, n=20)$ implies to be incorporated into clay minerals. In addition, $\mathrm{Ni}(r=0.63), \mathrm{Sc}(r=0.89), \mathrm{Cu}(r=0.69)$ and $\mathrm{V}(r=0.55)$ show significant positive correlation with $\mathrm{Al}_{2} \mathrm{O}_{3}$ due to their association with phyllosilicates. The enrichment of $\mathrm{Ni}$ in the studied samples is an indicator of slight mafic contribution in the source rock.

\subsection{Rare earth elements}

The determined REE contents in the Jhuran sandstones are given in table 4. The detection limit for the REE concentrations were also given in table 4 (Armstrong-Altrin et al. 2015). The 


\begin{tabular}{|c|c|c|c|c|c|}
\hline & $\vec{E} D$ & 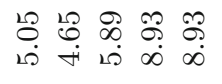 & 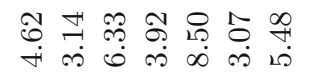 & 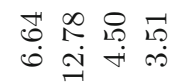 & 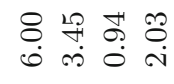 \\
\hline & & ำ & 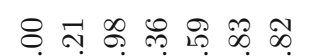 & ఠ̆ & Bి $\infty$ ค \\
\hline & ง & $\dot{m} \dot{\circ} \dot{\infty} \dot{\circ} \dot{\circ}$ & 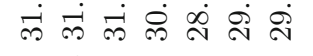 & 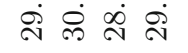 & 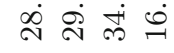 \\
\hline & बें & 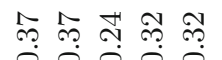 & 光 & F & $\infty \begin{array}{c}\infty \\
\infty \\
\infty\end{array}$ \\
\hline & & $\begin{array}{lllll}0 & 0 & 0 & 0 & 0 \\
1 & 4 & 0 & 19 & 10\end{array}$ & 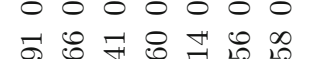 & 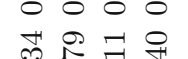 & $\begin{array}{llll}0 & 0 & 0 & 0 \\
0 & \cdots & 0 & \sharp\end{array}$ \\
\hline & 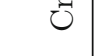 & 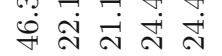 & 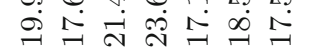 & 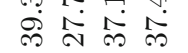 & 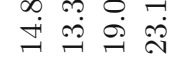 \\
\hline & ن & จุ & 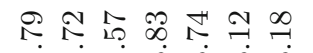 & 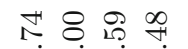 & की \& \\
\hline & & $\begin{array}{lllll}N & \sim & \sim & m & m \\
m & \sim & 0 & m & \infty\end{array}$ & 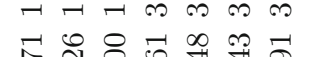 & 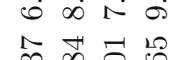 & $\begin{array}{ll}-1 & 0 \\
- & 0\end{array}$ \\
\hline & $\lambda$ & 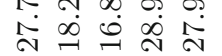 & 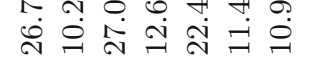 & 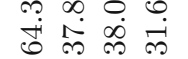 & 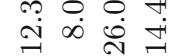 \\
\hline & i & 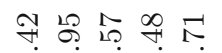 & 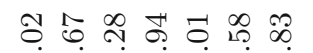 & 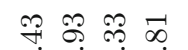 & $=10$ กิ \\
\hline & & $\dot{\Lambda}$ is $\dot{\theta} \dot{r} \dot{+}$ & 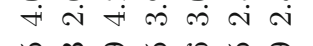 & $\infty \dot{+} \dot{\infty}$ & $i$ \\
\hline & $b$ & 萑 & 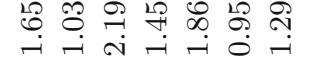 & 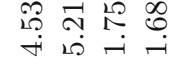 & 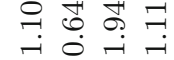 \\
\hline & F & 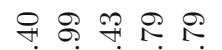 & 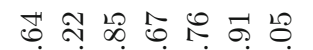 & \& 8 . & ণิ \\
\hline & $E$ & $\dot{0}$ & $\stackrel{9}{\rightarrow} 10$ & $\ddot{\theta} \dot{\theta} \dot{0}$ & \\
\hline & $\hat{D_{1}}$ & 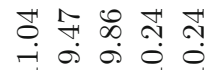 & 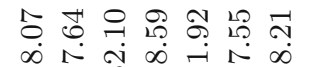 & 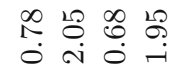 & 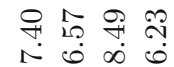 \\
\hline & & $\infty$ & v요 & in & $\widehat{\gamma}$ \\
\hline & $E$ & R & & & \\
\hline & \pm & 苛 & 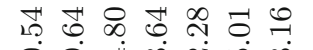 & 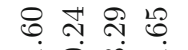 & \\
\hline & H & & ה $20^{\circ}$ & $\dot{-1}$ & \\
\hline & & 농 & Nִ $\stackrel{\infty}{\rightarrow}$ & $\stackrel{10}{\rightarrow}$ 구 & \\
\hline & $m$ & 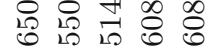 & 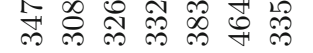 & 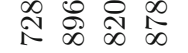 & $\sim N \sim$ \\
\hline & $v^{2}$ & हि: & 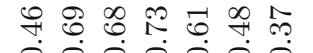 & 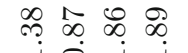 & ก้ \\
\hline & & हि 20 & 오는드. & $\infty 18 \infty$ & 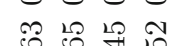 \\
\hline & $\vec{z}$ & 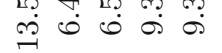 & 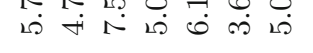 & 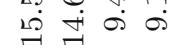 & $\dot{+}-\dot{-}$ \\
\hline & & 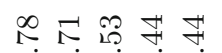 & 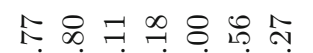 & 붕 & \\
\hline & $\grave{N}$ & 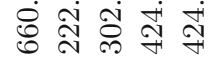 & ஸे & & \\
\hline & r & 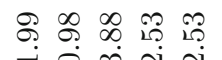 & 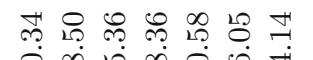 & 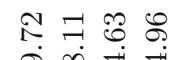 & \\
\hline & $\Omega$ & & & & \\
\hline & $\overrightarrow{2}^{2}$ & คి & 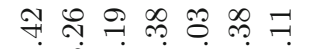 & $\infty$ & \\
\hline & صئ & & N & $\infty \infty$ & \\
\hline & שீ & 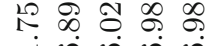 & 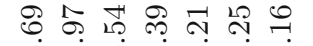 & రิ & \\
\hline & & $\stackrel{\rho}{\rightarrow} \infty$ & 8 & & \\
\hline & ง & 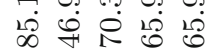 & iิ่ & $\begin{array}{lll}20 & 10 & 10\end{array}$ & \\
\hline & $=$ & 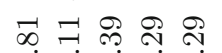 & भ & 2 8 \& & ปิ \\
\hline & 0 & $\stackrel{100}{20}$ & 字年 字字 & 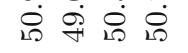 & 氷 \\
\hline & 7 & 로 ㅇำ 드 유 윰 & ๑ & t? & ? \\
\hline & Z & 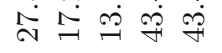 & 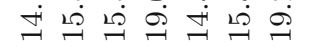 & 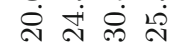 & $\stackrel{9}{\rightarrow}$ \\
\hline & ن & 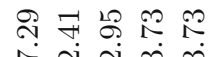 & 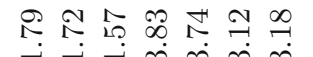 & : & \\
\hline & & 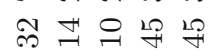 & 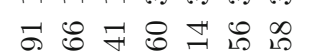 & 교요요 & $\infty$ \\
\hline & [] & $\stackrel{+}{N} \stackrel{+}{N}$ & $\therefore \stackrel{0}{\sim}$ & 穴 命 & $\ddot{+}$ \\
\hline & & $\stackrel{\mathbb{1}}{\mathbb{1}}$ & 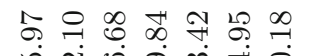 & శి & ชै 8 i \\
\hline & & 每 & $A \mathrm{a}+\mathrm{a}$ & 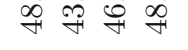 & $\stackrel{\infty}{\rightarrow} \underset{\sim}{\infty}$ \\
\hline & 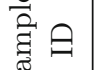 & 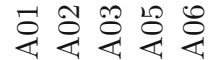 & 8 & $\exists$ & \\
\hline & & & & & \\
\hline & & s & 1 & 恶 & 䍘 \\
\hline & & & & $\pi$ & \\
\hline
\end{tabular}




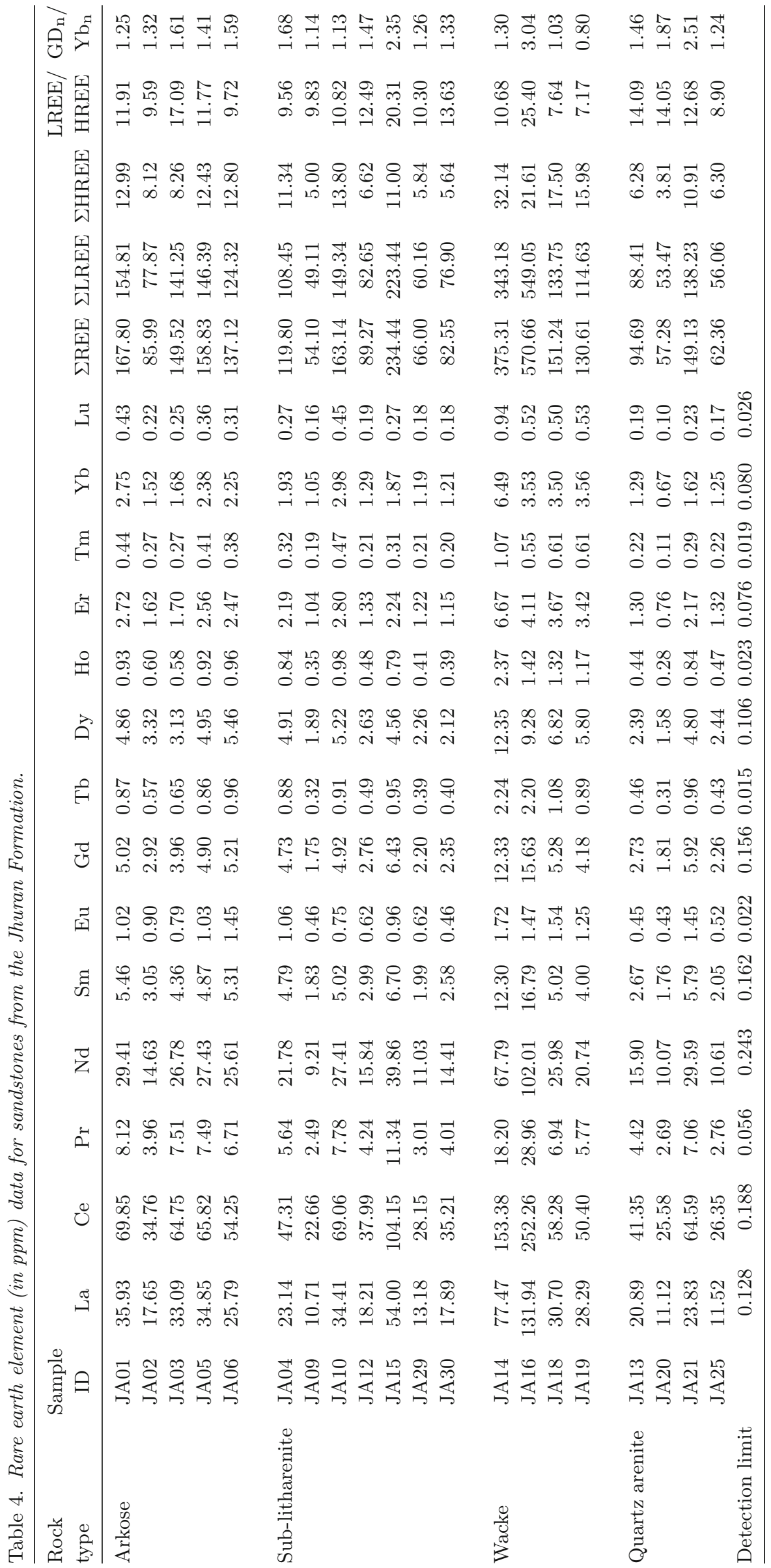


chondrite-normalized values display relatively similar to UCC pattern (figure 6c) with slight enrichment and depletion. The average $\Sigma$ REE concentrations of all sandstones from the Jhuran Formation are slightly higher than UCC values. Considering individual sandstones, the total REE in arkose (140 ppm, $n=5)$, sub-litharenite (115.6 ppm, $n=7)$ and quartz arenite (90.8 ppm, $n=4)$ are comparatively lower than UCC values and higher in wacke (307 ppm, $n=4)$. The enrichment of $\Sigma$ REE in wacke and depletion in quartz arenite reflects their grain size influence and amount of clay contents. The values of $\Sigma R E E$, heavy REE (HREE) and light REE (LREE) are separately correlated with $\mathrm{Al}_{2} \mathrm{O}_{3}$, which show significant positive correlation $0.50,0.48$ and $0.7(n=20)$ suggest that phyllosilicates are important in these samples in hosting REE.

The average ratio of $\Sigma$ LREE/ $\mathrm{HHREE}$ in the studied samples is 12.38 . The chondrite-normalized (LREE) pattern in figure 6(c) demonstrates their higher enrichment (143.5 ppm) in Jhuran sandstones than in UCC, relatively flat HREE profile (11.4 ppm) and negative $\mathrm{Eu}\left(\mathrm{Eu} / \mathrm{Eu}^{*}=0.66 \mathrm{ppm}\right)$ anomaly. Although, significant variations in the concentration of $\Sigma$ REE among the Jhuran sandstones are observed, but there is no overall difference in Eu anomaly is noticed. The ratios of $\mathrm{Gd}_{\mathrm{N}} / \mathrm{Yb}_{\mathrm{N}}$ of arkose, sub-litharenite, wacke and quartz arenite are $<2(0.8-3.04)$, which is suggestive of post-Archean source rock; however, few samples of wacke and sub-litharenite falls in Archean field (figure 15).

\section{Discussion}

\subsection{Palaeoweathering pattern}

Major element geochemistry and mineralogy of siliciclastic sedimentary rocks is greatly influenced by the intensity of chemical weathering at the source region, physical sorting and diagenesis (Nesbitt and Young 1982; McLennan 1993). Generally, feldspar is the more reactive mineral in the upper crust during chemical weathering and diagenesis, which results in the formation of clay minerals (Nesbitt and Young 1984; Taylor and McLennan 1985). The chemical weathering in the Jhuran sandstones were quantified using chemical index of alternation (CIA) (Nesbitt and Young 1982), which is widely used paleoweathering index by formula

$$
\mathrm{CIA}=\frac{\mathrm{Al}_{2} \mathrm{O}_{3}}{\left(\mathrm{Al}_{2} \mathrm{O}_{3}+\mathrm{CaO}^{*}+\mathrm{Na}_{2} \mathrm{O}+\mathrm{K}_{2} \mathrm{O}\right) \times 100} .
$$

The above equation is calculated using molar proportion ratio of respective elements, where $\mathrm{CaO}^{*}$ represents the quantity of $\mathrm{CaO}$ incorporated in silicates/non-carbonate minerals only. The $\mathrm{CaO}$ in the Jhuran sandstone samples varies from 0.36 to 14.12 (wt\%). The higher concentration of $\mathrm{CaO}$ in the studied samples were corrected using the method developed by McLennan (1993) to discriminate the content of $\mathrm{CaO}$ in silicate fraction $\left(\mathrm{CaO}^{*}\right)$ and non-silicate fraction. Higher concentration of $\mathrm{CaO}$ can be attributed to the presence of rich calcite cement and dolomitic matrix. For each sandstone type, the average calculated CIA values varies from $58.3-65.7 \%$ (arkose), 46.6-57.6\% (sublitharenite), $64.5-71.7 \%$ (wacke) and $15.6-36.8 \%$ (quartz arenite). Overall the calculated CIA values range from 15.6 to $71.7 \%$ for the Jhuran Formation sandstones. In general, the CIA value of typical unweathered granite to granodiorite rock is below 50, while feldspar, mica, illite and kaolinite minerals have 75, 75-85, 100, respectively (Nesbitt and Young 1982). Higher CIA values (>70) suggest intense chemical weathering (Armstrong-Altrin et al. 2013, 2014; Deepthi et al. 2013; Sun et al. 2013).

The CIA values of arkose, sub-litharenite and wacke imply low to moderate intensity of chemical weathering at the source area, whereas quartz arenite $(<50)$ has CIA value lower than upper continental crust. Thus the low range of CIA value in these sandstones may not be very effective to characterize the original paleoweathering condition at the source area. The compositional changes associated with paleoweathering and source rock composition of the Jhuran sandstones are evaluated by plotting the CIA data on $\mathrm{A}-\mathrm{CN}-\mathrm{K}\left(\mathrm{Al}_{2} \mathrm{O}_{3}-\left(\mathrm{CaO}^{*}+\mathrm{Na}_{2} \mathrm{O}\right)-\right.$ $\left.\mathrm{K}_{2} \mathrm{O}\right)$ triangular diagram after Nesbitt and Young (1984), where $\mathrm{CaO}^{*}$ depicts $\mathrm{Ca}$ in silicate fractions only. All the sandstone samples plotted in $\mathrm{A}-\mathrm{CN}-$ $\mathrm{K}$ ternary diagram (figure 7 ) show deviation from general weathering trend parallel to $\mathrm{A}-\mathrm{CN}$ edge except wacke sandstone. The grouping of wacke and arkose samples close to illite composition indicates moderate to intense weathering condition at source area and consistent with predicted path. Whereas the sub-litharenite plot near to muscovite point and quartz arenite sample plot along $\mathrm{A}-\mathrm{K}$ join due to depletion of $\mathrm{Al}_{2} \mathrm{O}_{3}$ and $\mathrm{Na}_{2} \mathrm{O}$. The depletion of these elements resulted in low CIA values in quartz arenite, which gives little clue about paleoweathering condition of quartz arenite. The more smooth and elevated values of CIA indicate the stable tectonic settings and steady-state weathering trend. Whereas active tectonism results wide range of CIA values in the sediments due to erosion of all zones of weathering profile by rapid upliftment (Nesbitt et al. 1997; Selvaraj and Chen 2006; Armstrong-Altrin 2009). The wide range of CIA value in the Jhuran sandstone samples probably indicate that the sediments originated from non-steady state weathering through active tectonism. In addition, the ratio of $\mathrm{Th} / \mathrm{U}$ can also 


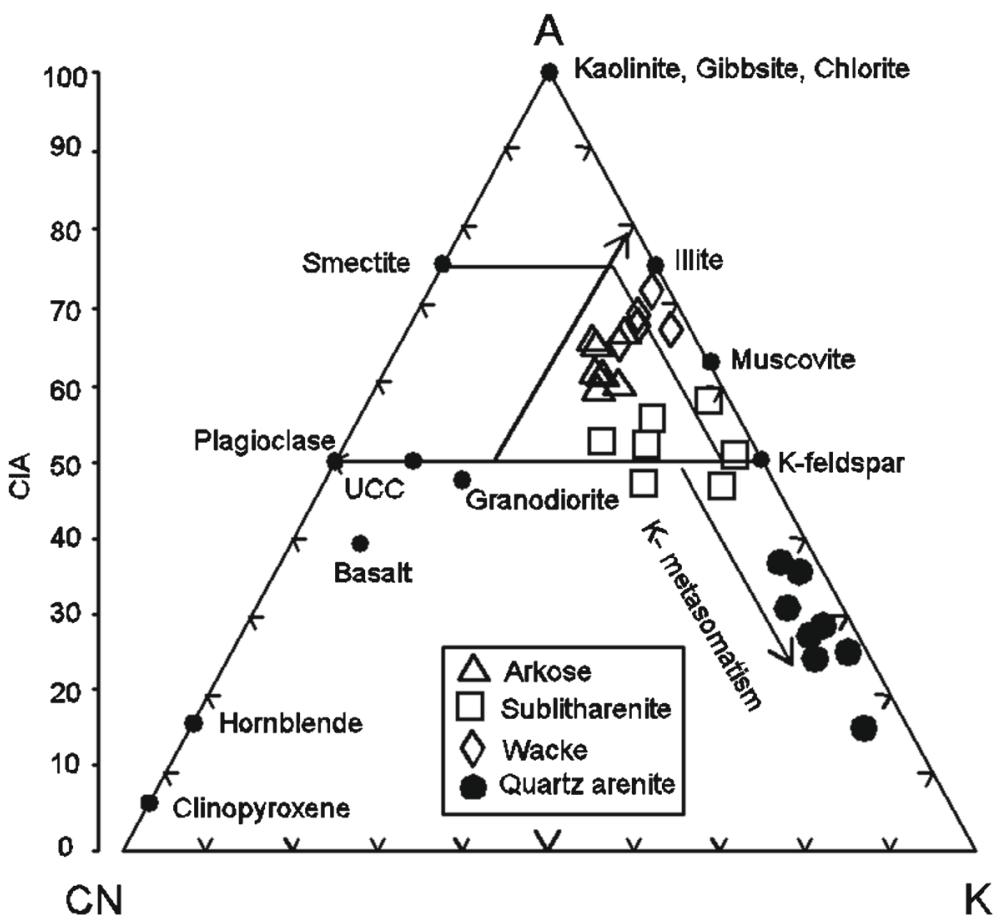

Figure 7. A-CN-K ternary diagram (after Nesbitt and Young 1982) for sandstones of the Jhuran Formation $\left(\mathrm{A}^{-}=\mathrm{Al}_{2} \mathrm{O}_{3}\right.$, $\mathrm{CN}=\mathrm{CaO}^{*}+\mathrm{Na}_{2} \mathrm{O}, \mathrm{K}=\mathrm{K}_{2} \mathrm{O}$ ). $\mathrm{CaO}^{*}$ depicts $\mathrm{CaO}$ incorporated in silicate fraction. UCC values (Taylor and McLennan 1985).

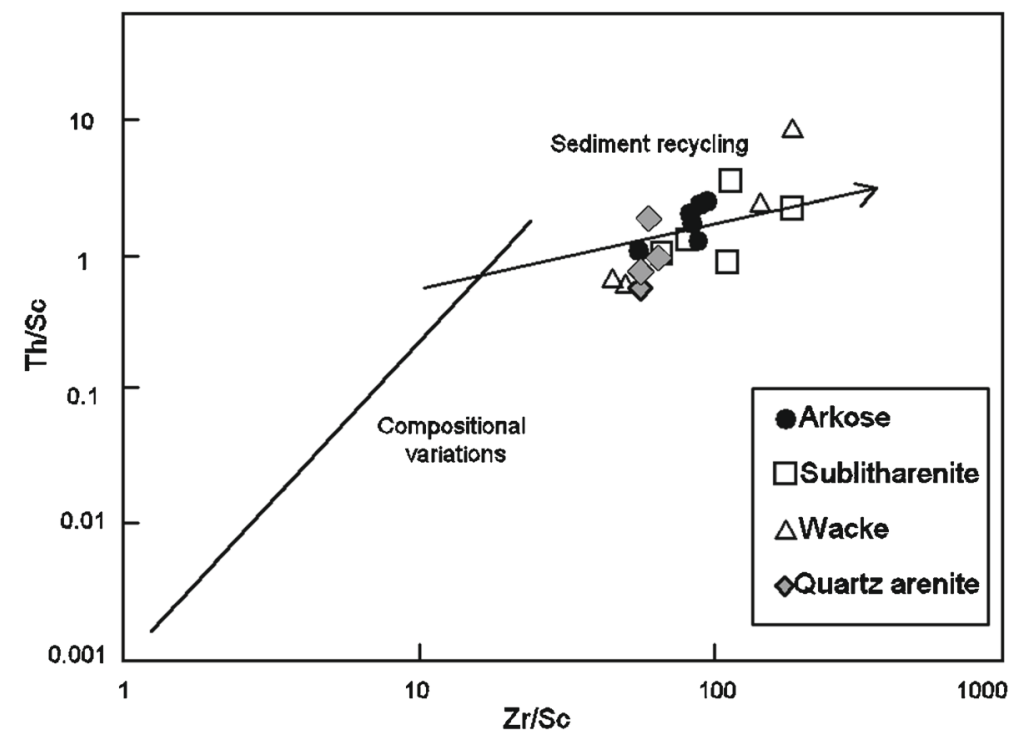

Figure 8. Binary scatter diagram of Zr/Sc against Th/Sc (McLennan et al. 1993) showing single trend for the Jhuran sandstones. The trend represents the sediments of the Jhuran Formation significantly affected by sediment sorting and recycling.

indicate the source rock weathering pattern since $\mathrm{U}$ is generally removed during intense weathering (McLennan et al. 1993). The average $\mathrm{Th} / \mathrm{U}$ ratio in the arkose, sub-litharenite, wacke and quartz arenite samples are 6.7, 5.0, 6.8 and 3.1, respectively (table 3 ), which are suggestive of moderate to intense weathering in the source region except for quartz arenite.

\subsection{Sediment sorting and recycling}

Clastic sediments undergo hydraulic/mechanical sorting during transportation which significantly influences the bulk chemical composition of the resultant rocks by enriching certain minerals due to fractionation (Cullers et al. 1979; McLennan 1989; Bauluz et al. 2000; Armstrong-Altrin 2009; Singh 
2009; Wu et al. 2013). Index of compositional variability $\left[\left(\mathrm{Fe}_{2} \mathrm{O}_{3}+\mathrm{K}_{2} \mathrm{O}+\mathrm{Na}_{2} \mathrm{O}+\mathrm{CaO}+\mathrm{MgO}+\mathrm{MnO}+\right.\right.$ $\left.\left.\mathrm{TiO}_{2}\right) / \mathrm{Al}_{2} \mathrm{O}_{3}, \mathrm{ICV}\right]$ is used to study the geochemical variability due to hydraulic sorting (Cox et al. 1995). Generally, ICV values $>0.84$ show the presence of rock forming minerals, while $<0.84$ is characteristic of altered products, viz., clay minerals (Cox et al. 1995; Cullers 2000; Armstrong-Altrin et al. 2014). The ICV value of arkose (2.00-2.94), sublitharenite (5.61-8.80), wacke (1.99-2.87) and quartz arenite $(>25)$ in the studied samples are $>0.84$ (table 2), which suggests the enrichment of primary minerals. In addition, ICV $>1$ is suggestive of first cycle of sediments, which is well reflected in arkose, sub-litharenite and wacke samples. Also, $\mathrm{SiO}_{2} / \mathrm{Al}_{2} \mathrm{O}_{3}$ ratio is calculated to know the textural maturity of sediments, higher $\mathrm{SiO}_{2} / \mathrm{Al}_{2} \mathrm{O}_{3}$ values indicate maturity of sediments (Ahmad and Chandra 2013; Armstrong-Altrin et al. 2014). The $\mathrm{SiO}_{2} / \mathrm{Al}_{2} \mathrm{O}_{3}$ ratio of arkose and wacke samples

Table 5. XRD data of zircon peaks in the analyzed rock samples.

\begin{tabular}{|c|c|c|c|}
\hline Sl. no & Sample & $2 \Theta(\operatorname{deg})$ & d spacing $(\AA ̊)$ \\
\hline \multirow[t]{4}{*}{1} & K2 2.4 & 27.0 & 3.339 (zircon) \\
\hline & Arkose & 36.0 & 2.485 (zircon) \\
\hline & JA 01 & 43.2 & 2.086 (zircon) \\
\hline & & 55.0 & 1.671 (zircon) \\
\hline \multirow[t]{6}{*}{2} & K2 7.2 & 21.0 & 4.248 (zircon) \\
\hline & Arkose & 26.5 & 3.293 (zircon) \\
\hline & JA 05 & 36.0 & 2.487 (zircon) \\
\hline & & 43.2 & 2.087 (zircon) \\
\hline & & 47.5 & 1.906 (zircon) \\
\hline & & 55.0 & 1.671 (zircon) \\
\hline \multirow[t]{4}{*}{3} & $\mathrm{~K} 213.4 \mathrm{a}$ & 21.0 & 4.257 (zircon) \\
\hline & Sub-litharenite & 43.2 & 2.086 (zircon) \\
\hline & JA 12 & 46.0 & 1.980 (zircon) \\
\hline & & 55.0 & 1.671 (zircon) \\
\hline \multirow[t]{5}{*}{4} & K2 18.4 & 21.0 & 4.262 (zircon) \\
\hline & Sub-litharenite & 27.0 & 3.297 (zircon) \\
\hline & JA 29 & 43.0 & 2.091 (zircon) \\
\hline & & 47.5 & 1.909 (zircon) \\
\hline & & 55.0 & 1.671 (zircon) \\
\hline \multirow[t]{3}{*}{5} & K2 17.4 & 21.0 & 4.288 (zircon) \\
\hline & Wacke & 45.8 & 1.983 (zircon) \\
\hline & JA 16 & 55.0 & 1.675 (zircon) \\
\hline \multirow[t]{4}{*}{6} & K2 19.3 & 21.0 & 4.257 (zircon) \\
\hline & Wacke & 27.0 & 3.297 (zircon) \\
\hline & JA 19 & 43.0 & 2.088 (zircon) \\
\hline & & 55.0 & 1.672 (zircon) \\
\hline \multirow[t]{3}{*}{7} & K2 14.1 & 21.0 & 4.293 (zircon) \\
\hline & Quartz arenite & 44.5 & 2.031 (zircon) \\
\hline & JA 13 & 55.0 & 1.676 (zircon) \\
\hline \multirow[t]{3}{*}{8} & K2 20.4 & 21.0 & 4.251 (zircon) \\
\hline & Quartz arenite & 45.0 & 2.019 (zircon) \\
\hline & JA 20 & 55.0 & 1.671 (zircon) \\
\hline
\end{tabular}

varies between 6.80-13.01 and 5.05-6.82, respectively, while they are 19.70-31.59 and $>103$ in sublitharenite and quartz arenite, respectively, infer that these sediments are highly matured than arkose and wacke.

The $\Sigma$ REE concentration in Jhuran sandstones, i.e., arkose $(139.9, n=5)$, sub-litharenite (115.6, $n=7)$, wacke (307, $n=4$ ) and quartz arenite $(90.9, n=4)$ varies considerably in spite of its immobility during weathering and transportation. None of the sandstone types of the Jhuran Formation show equivalent amount of total REE normalized to UCC and PAAS because of their grain-size variability and heavy mineral concentration (Condie et al. 1995; Cullers et al. 1997).

Also, the concentration of high weathering resistant phases (like zircon) in the samples can reflect the sorting and recycling processes involved (Armstrong-Altrin et al. 2012). Figure 8 shows that $\mathrm{Th} / \mathrm{Sc}$ is plotted against $\mathrm{Zr} / \mathrm{Sc}$ to depict the enrichment of $\mathrm{Zr}$ in the studied samples. In general, $\mathrm{Zr} / \mathrm{Sc}$ ratio increases by addition of zircon mineral during sorting and/or recycling processes (McLennan et al. 1993; Armstrong-Altrin et al. 2012). The Jhuran

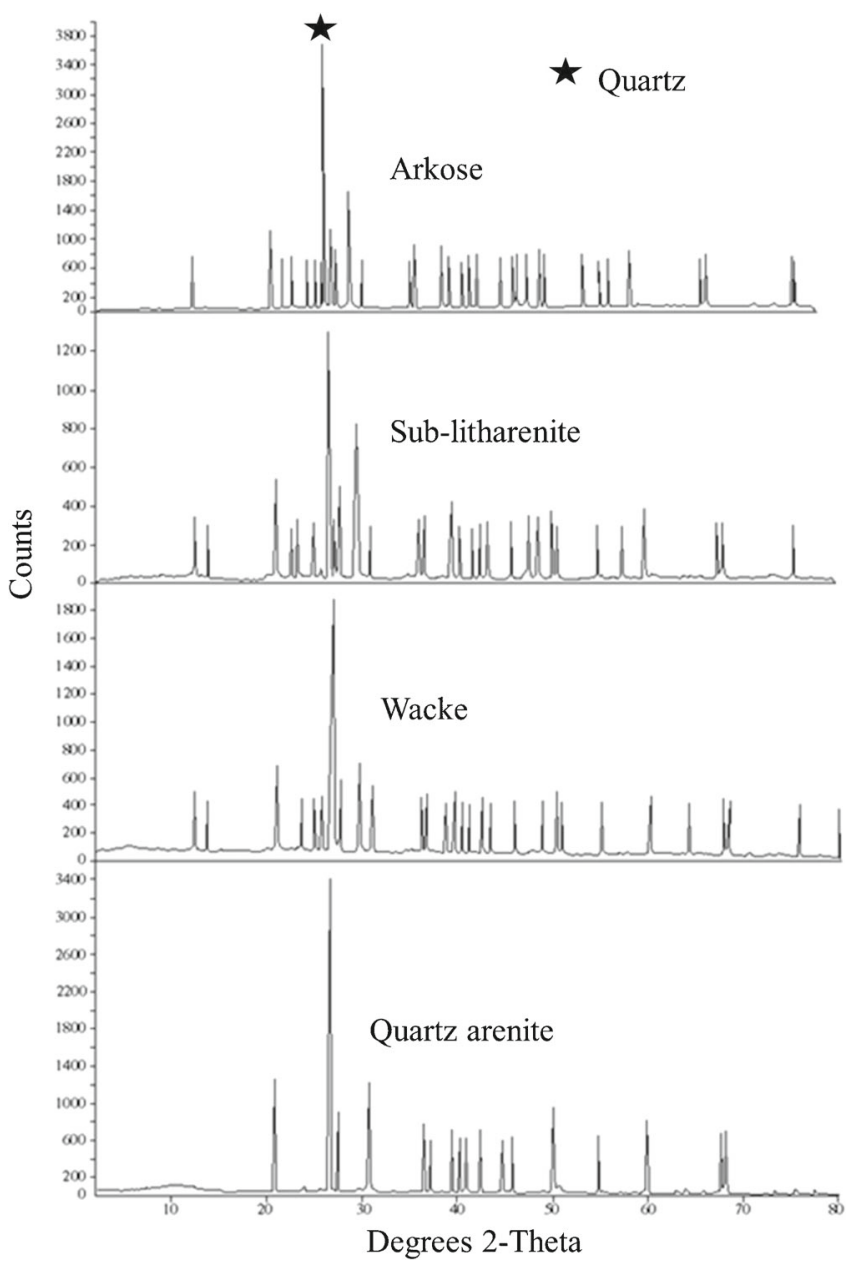

Figure 9. X-ray diffraction patterns of the Jhuran sandstone samples. 
sandstone samples fall in the trend 2 with enrichment of zircon indicates the significant influence of sorting and recycling of sediments. It is further supported by the positive correlation of $\mathrm{Zr}$ against Th $(r=0.75, n=20)$ and $\mathrm{Zr}$ against total REE $(r=0.8, n=20)$. Hence, it can be interpreted that both grain-size fraction and heavy mineral (zircon) content are responsible for difference in contents of total REE in the Jhuran sandstone samples.

XRD data of zircon peaks in the analysed samples are shown in table 5. Figure 9 shows the XRD patterns of arkose, sub-litharenite, wacke

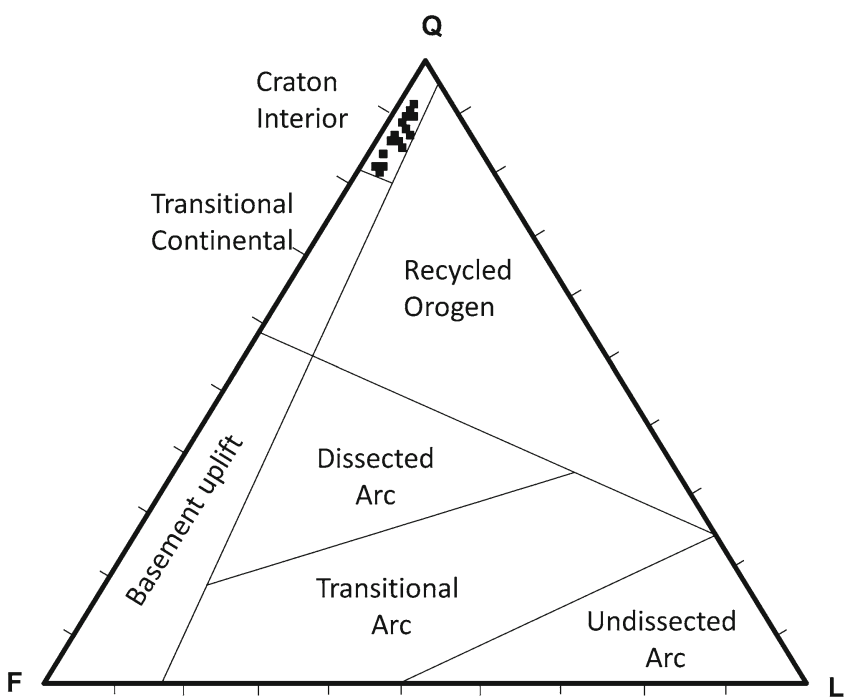

Figure 10. Tectonic setting discrimination diagram for the Jhuran sandstones based on Q-F-Lt (Dickinson and Suczek 1979). and quartz arenite samples. The distribution of zircon in arkose is comparatively higher than that observed in quartz arenite and wacke. They are detrital in nature, allogenic and are derived from a granitic source. The availability of zircon population in these samples shows their resistance to transportation and weathering, hence indicating their proximity to the source of formation.

\subsection{Tectonic setting}

The petrographic study reveals that the studied sediments are characterized with higher proportions of monocrystalline quartz, smaller amount of polycrystalline quartz, more K-feldspar than plagioclase and a minor amount of rock fragments. Many authors have successfully established the tectonic environment by the proportions of frame work grains (Crook 1974; Schwab 1975; Potter 1975, 1986; Dickinson and Suczek 1979; Dickinson et al. 1983; Taylor and McLennan 1985). On the Qt-F-L diagram of Dickinson and Suczek (1979), the samples of the Jhuran Formation fall within the craton interior margin as shown in figure 10 . The frame work grain properties (like quartz and feldspar) of studied formations are consistent with those of sediments deposited in a craton interior margin. Sandstones that fall within the passive continental block are chiefly derived from exposed shield areas and platforms or from uplifted areas.

Tectonic setting discrimination diagrams using $\mathrm{SiO}_{2}$ content and $\mathrm{K}_{2} \mathrm{O} / \mathrm{Na}_{2} \mathrm{O}$ ratios proposed by Bhatia (1983) and Roser and Korsch (1986) for

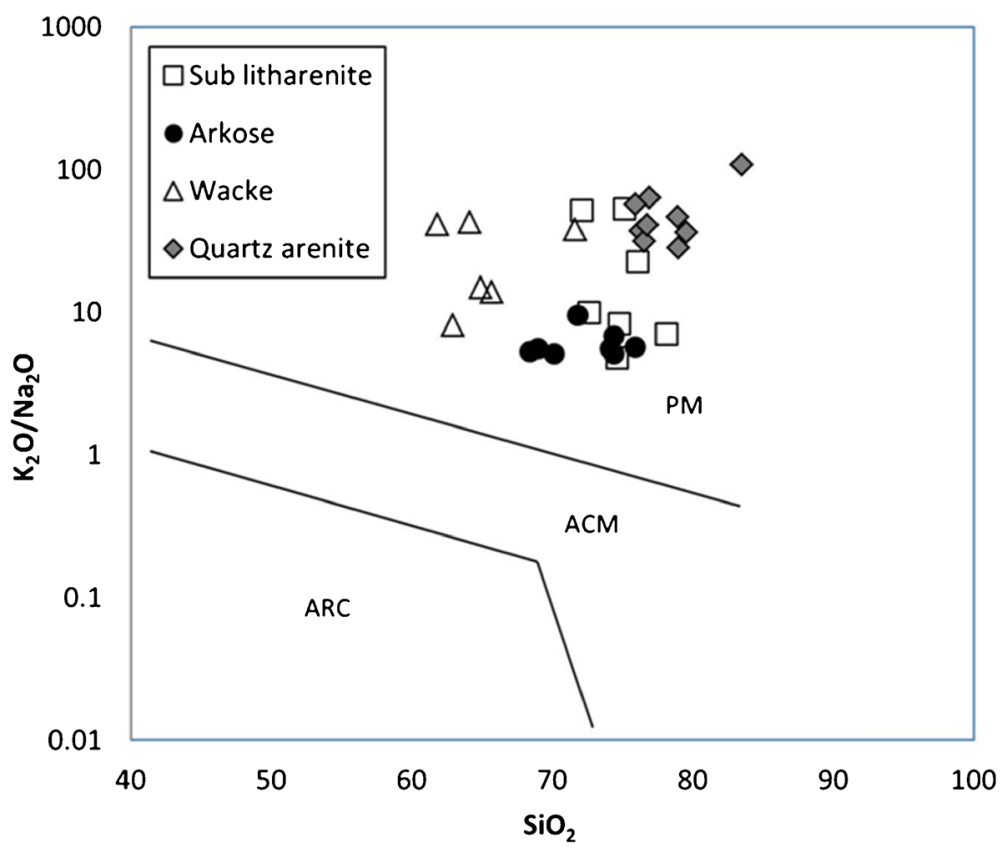

Figure 11. Tectonic discrimination diagram of $\mathrm{SiO}_{2}$ vs. $\mathrm{K}_{2} \mathrm{O} / \mathrm{Na}_{2} \mathrm{O}$ after Bhatia (1983) and Roser and Korsch (1986), where in three fields are passive margin, active continental margin and arc settings. 
sedimentary rocks is used to identify the tectonic setting of unknown basins that are still extensively used by many authors thus, shows consistency with the modal analysis (Drobe et al. 2009; Gabo et al. 2009; Bhushan and Sahoo 2010; Maslov et al. 2010; Wani and Mondal 2010). The Jhuran sediments plot within the passive continental margin (figure 11), which represents quartz-rich sediments derived from adjacent continental stable or rifted margin.

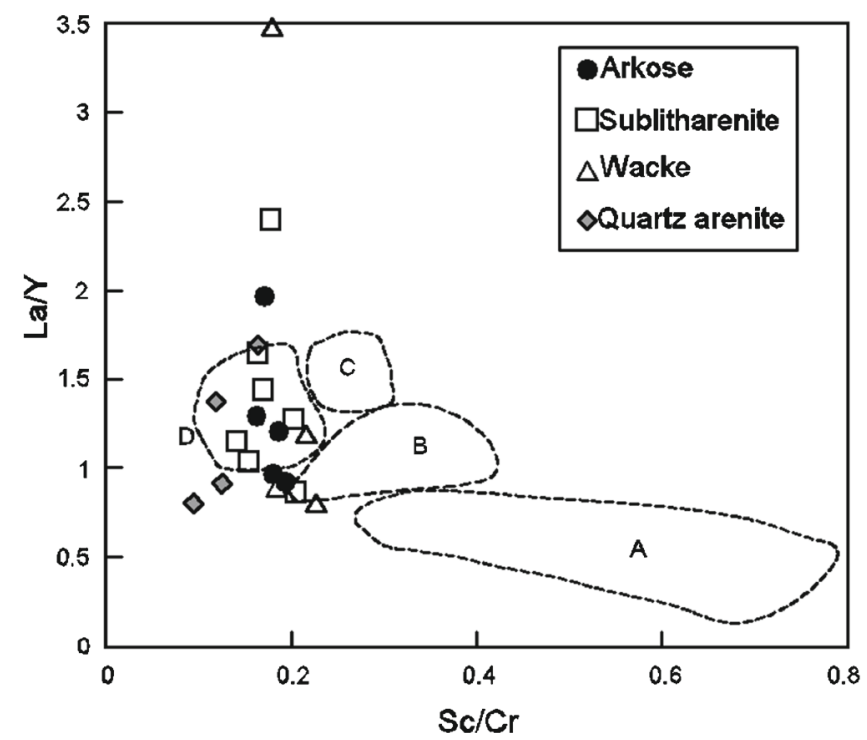

Figure 12. Plot of the trace element compositions for Jhuran sandstones represents $\mathrm{Sc} / \mathrm{Cr}$ vs. La/Y (after Bhatia and Crook 1986). A, B, C and D are oceanic island arc, continental island arc, active continental margin and passive continental margin settings, respectively.
Bhatia and Crook (1986) proposed various plots using certain immobile trace elements (for example, La, Th, Y, Sc, Cr and Zr) to discriminate the provenance and tectonic settings of clastic sediments and later successfully used by recent authors (Sun et al. 2012; Yang et al. 2012; Jorge et al. 2013). The bivariate plot of $\mathrm{Sc} / \mathrm{Cr}$ vs. La/Y (figure 12) indicates that Jhuran sandstone samples were deposited in passive continental margin settings since most of the samples fall within the passive field and some are scattered, which is consistent with the plots based on the framework grains (figure 10) and major elements (figure 11).

\subsection{Source rock and provenance}

To identify the source rock composition using discrimination diagram of Roser and Korsch (1988) (figure 13), wherein all the samples of the Jhuran sandstone fall within the quartzose sedimentary provenance imply that they were derived from quartz rich or recycled sources. However, angular to sub-angular grains of quartz arenite (figure 3e) suggests that the sediments are texturally immature and indicate first cycle sediments transported to a shorter distance. This statement is confirmed by petrographic analysis.

The bivariate plot of La/Sc vs. Th/Co (Cullers 2002) (figure 14) support the silicic source rock composition. REEs are most widely used as an indicator of the source rock composition because they are virtually insoluble and immobile during sedimentary processes and preserve the signature

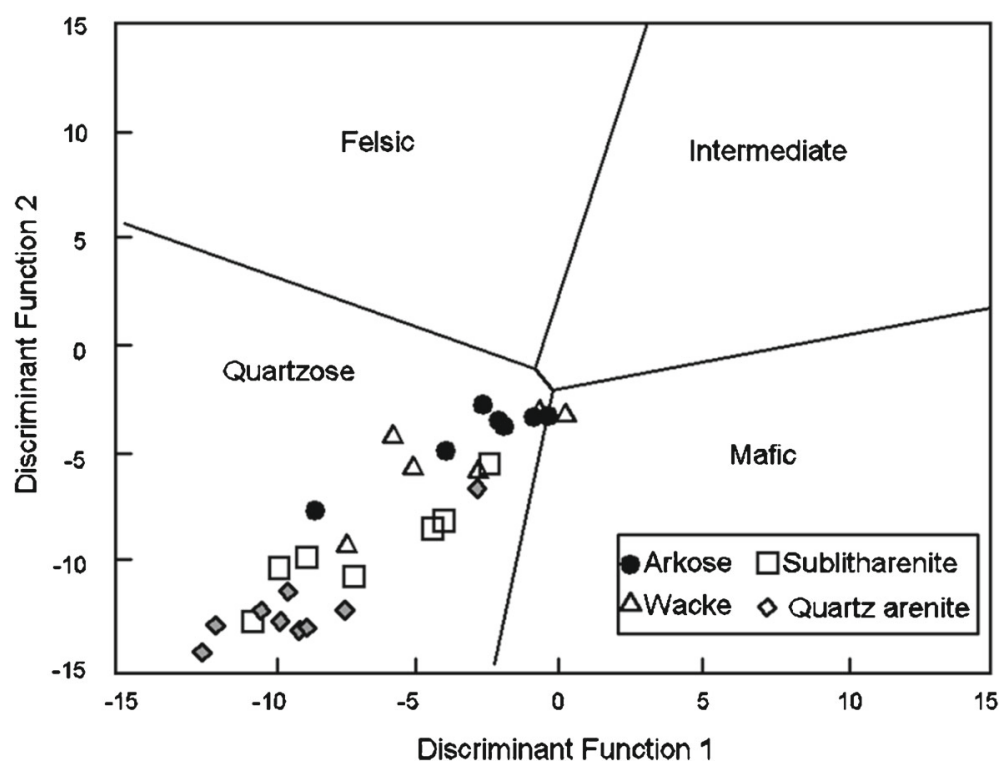

Figure 13. Provenance discrimination diagram for sandstones of the Jhuran Formation (after Roser and Korsch 1988). Discriminate function $1=\left(-1.773 \times \mathrm{TiO}_{2} \%\right)+\left(0.607 \times \mathrm{Al}_{2} \mathrm{O}_{3} \%\right)+\left(0.76 \times \mathrm{Fe}_{2} \mathrm{O}_{3} \%\right)(-1.5 \times \mathrm{MgO} \%)+\left(0.616 \times \mathrm{CaO}_{0} \%\right)+$ $\left(0.509 \times \mathrm{Na}_{2} \mathrm{O} \%\right)+\left(-1.22 \times \mathrm{K}_{2} \mathrm{O} \%\right)+(-9.09)$. Discriminate function $2=\left(0.445 \times \mathrm{TiO}_{2} \%\right)+\left(0.07 \times \mathrm{Al}_{2} \mathrm{O}_{3} \%\right)+$ $\left(0.25 \times \mathrm{Fe}_{2} \mathrm{O}_{3} \%\right)+(1.142 \times \mathrm{MgO} \%)+\left(0.432 \times \mathrm{Na}_{2} \mathrm{O} \%\right)+\left(1.426 \times \mathrm{K}_{2} \mathrm{O} \%\right)+(-6.861)$. 


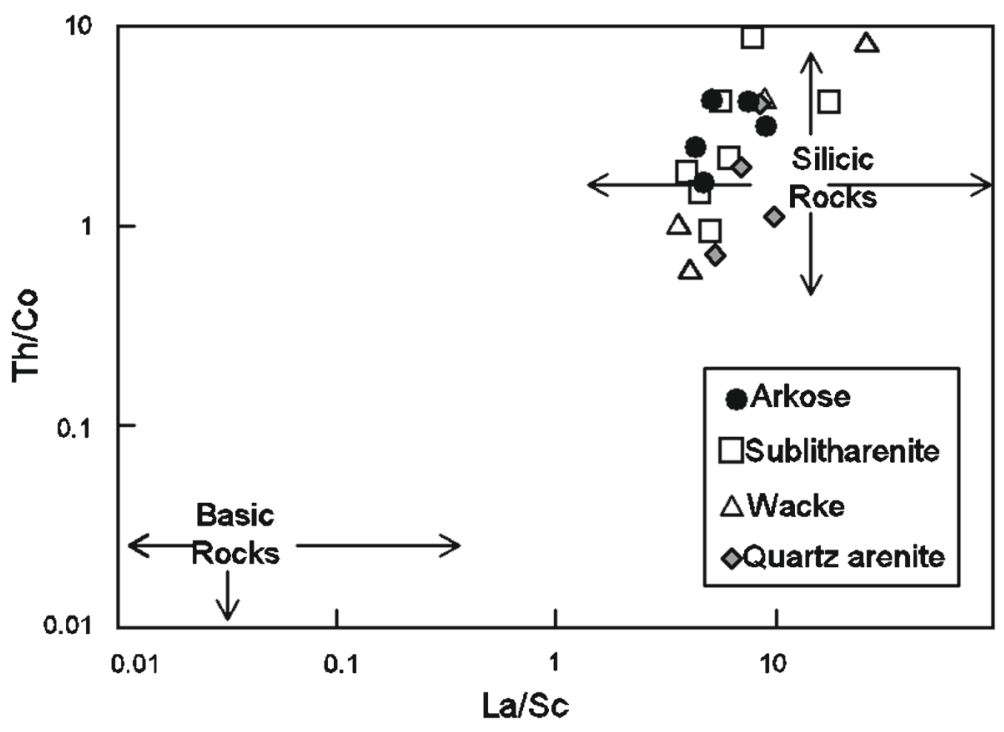

Figure 14. Bivariate plot of La/Sc vs. Th/Co (after Cullers 2002) shows that all the samples of the Jhuran Formation plot in silicic rock source.

Table 6. Selected elemental ratios of Jhuran sandstones correlated with those of sediments derived from silicic and basic sources, UCC and PAAS.

\begin{tabular}{|c|c|c|c|c|c|c|c|c|c|c|}
\hline \multirow[b]{2}{*}{$\begin{array}{l}\text { Elemental } \\
\text { ratio }\end{array}$} & \multirow[b]{2}{*}{ Arkose $^{1}$} & \multirow[b]{2}{*}{ Sub-litharenite ${ }^{1}$} & \multirow[b]{2}{*}{ Wacke $^{1}$} & \multirow[b]{2}{*}{$\begin{array}{l}\text { Quartz } \\
\text { arenite }^{1}\end{array}$} & \multicolumn{2}{|c|}{ Coarse fractions } & \multicolumn{2}{|c|}{ Fine fraction } & \multirow[b]{2}{*}{$\mathrm{UCC}^{3}$} & \multirow[b]{2}{*}{ PAAS $^{3}$} \\
\hline & & & & & $\begin{array}{c}\text { Silicic } \\
\text { source }^{2}\end{array}$ & $\begin{array}{c}\text { Basic } \\
\text { source }^{2}\end{array}$ & $\begin{array}{c}\text { Silicic } \\
\text { source }^{2}\end{array}$ & $\begin{array}{c}\text { Basic } \\
\text { source }^{2}\end{array}$ & & \\
\hline $\mathrm{Eu} / \mathrm{Eu}^{*}$ & 57 & & .21 & & $0.40-0.94$ & $0.71-0.95$ & $0.32-0.83$ & $0.7-1.02$ & 0.63 & 0.60 \\
\hline $\mathrm{Th} / \mathrm{Co}$ & $1.70-$ & & $0.62-8$ & & $0.67-19.4$ & $0.04-1.4$ & $0.3-7.5$ & - & 0.63 & 0.63 \\
\hline $\mathrm{Th} / \mathrm{Sc}$ & $1.52-3.52$ & $1.13-5.25$ & $0.86-13.51$ & $0.78-2.72$ & $0.84-20.5$ & $0.05-0.22$ & $0.64-18.1$ & $0.05-0.4$ & 0.79 & 0.91 \\
\hline $\mathrm{La} / \mathrm{Sc}$ & $4.47-9.28$ & $4.01-17.97$ & $3.69-26.77$ & $5.43-10.18$ & $2.50-16.3$ & $0.43-0.86$ & $0.7-27.7$ & $0.4-1.1$ & 2.21 & 2.50 \\
\hline $\mathrm{La} / \mathrm{Co}$ & $4.93-11.22$ & $4.23-21.90$ & $2.98-16.50$ & $3.71-14.64$ & $1.80-13.8$ & $0.14-0.38$ & $1.4-22.2$ & - & 1.76 & 1.65 \\
\hline
\end{tabular}

${ }^{1}$ Present study.

${ }^{2}$ Cullers (2000), Cullers et al. (1988).

${ }^{3}$ Taylor and McLennan (1985).

of the source rock (Taylor and McLennan 1985; Cullers 1995; Armstrong-Altrin et al. 2014, 2015). Generally, low LREE/HREE ratios and small/ absence of $\mathrm{Eu}$ anomalies are indicative of basic rock source, whereas higher ratio and negative $\mathrm{Eu}$ anomaly indicate the silicic igneous rock sources (Cullers et al. 1987; Cullers 1994). The samples of the Jhuran sandstones show high ratio of LREE/ HREE and negative Eu anomaly (figure 6c) supported the silicic rock source. Table 6 shows the selected elemental ratios, i.e., $\mathrm{Eu} / \mathrm{Eu}^{*}, \mathrm{Th} / \mathrm{Co}$, $\mathrm{Cr} / \mathrm{Th}, \mathrm{Th} / \mathrm{Sc}, \mathrm{La} / \mathrm{Th}, \mathrm{La} / \mathrm{Sc}$ and La/Co of the Jhuran sandstone samples compared with other studies suggest that the studied sediments were derived from felsic rocks. The ratio of $\mathrm{Gd}_{\mathrm{N}} / \mathrm{Yb}_{\mathrm{N}}$ indicates the nature of source rocks composition of the continental crust (Taylor and McLennan 1985). The plot of $\mathrm{Eu} / \mathrm{Eu}^{*}$ vs. $(\mathrm{Gd} / \mathrm{Yb})_{\mathrm{N}}$ in figure 15 with the ratio of $\mathrm{Gd}_{\mathrm{N}} / \mathrm{Yb}_{\mathrm{N}}=0.8-3.04$ shows that all the samples fall within post-Archean field, which is suggestive of post-Archean felsic rocks which could act as source rock.

The REE data of present study is compared with geochemistry of Nagar Parkar Complex, which is located in the northern part of Kachchh basin. The chondrite normalized REE pattern of grey granites, pink granites, rhyolites and basic dykes from Nagar Parkar Complex (Laghari 2004; Ahmad and Chaudhry 2008) is closely associated with the studied sediments (figure $6 \mathrm{c}$ ). These rocks of Nagar Parkar complex are identified as possible source rock for the studied region with slight mafic input as it shows similar trend of studied samples. The negative Eu anomaly from the source rock is reflected in the sediments of the Jhuran Formation (figure 6c). Further detailed studies are required to understand the complexity and tectonic setting of Kachchh basin. 


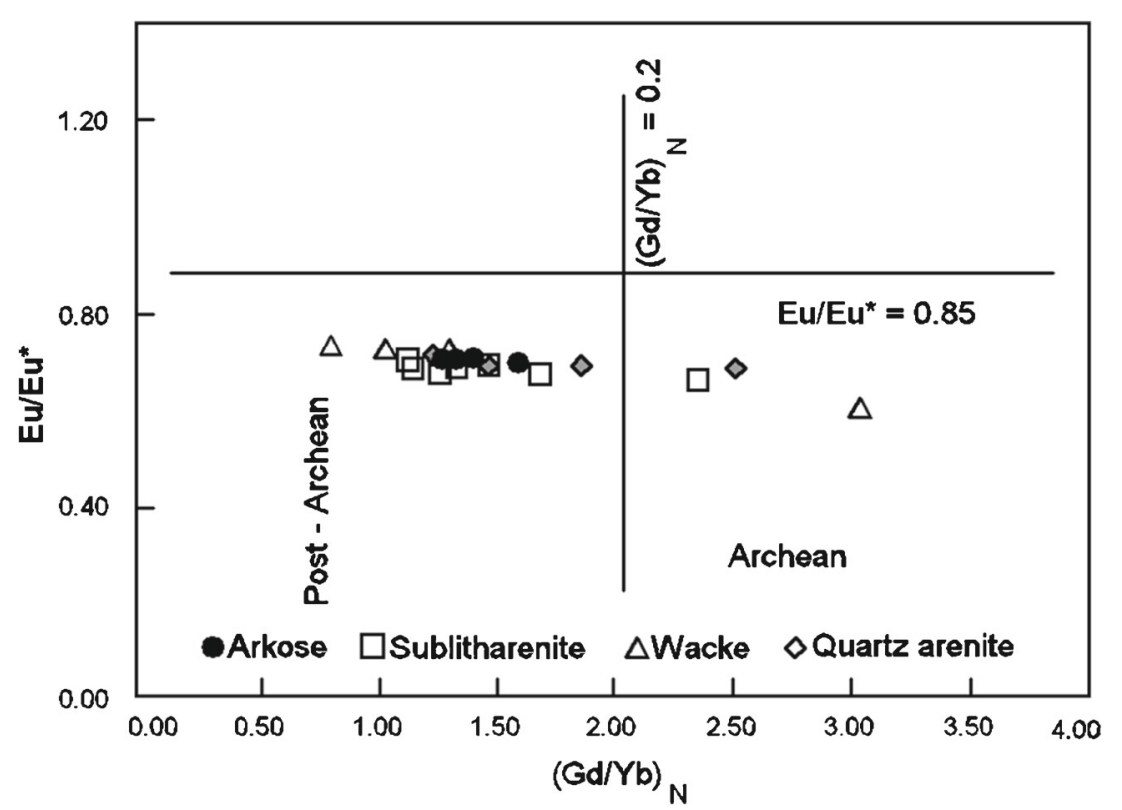

Figure 15. Plot of $(\mathrm{Gd} / \mathrm{Yb})_{\mathrm{N}}$ against Eu/Eu* of the Jhuran samples (after McLennan and Taylor 1991).

\section{Conclusions}

A comprehensive analysis based on petrography and geochemistry (major, trace and REE elements) were performed on the sandstones of the Jhuran Formation from Jara dome, Kachchh basin to deduce their palaeoweathering conditions, tectonic setting, source rock and provenance. The studied sandstone members of the Jhuran Formation have been analysed based on geochemical signatures to be arkose, sub-litharenite, wacke and quartz arenite type.

The value of CIA (15.6-71.7\%) for all the sandstones suggests moderate to intense degree of weathering at the source area and the wide variation indicates non-steady state of weathering. The enrichment of $\mathrm{Zr}$ in the samples suggests the multiple recycling of sediments.

Various tectonic discriminant diagrams based on petrographic observations, major and trace elements infer that the studied sandstones were deposited in a passive continental setting. The present study suggests that the sediments of the Jhuran Formation were chiefly derived from felsic rock sources, i.e., granite and granitoid compositions and show no mafic input which was further supported by negative Eu anomaly and $\mathrm{Zr}$ enrichment. Geochemical characteristics of the sandstones from this study indicate that the possible provenance is from Nagar Parkar ridge rocks in the northern part of the basin.

\section{Acknowledgements}

We thank the Director, CSIR-National Geophysical Research Institute (NGRI), Hyderabad, for the permission to publish this paper. Author (MV) thanks B Pandey, D B Pathak and Jai Krishna and G Papanna for their association in the field work and encouragement. Authors thank the anonymous reviewers for their helpful suggestions and also thank Prof. N V Chalapathi Rao, Editor-in-Chief, for constructive handling of the paper. MV thankfully acknowledges the Department of Science and Technology (DST), Govt. of India for the financial support (SR/S4/ES-261-2007).

\section{References}

Ahmad I and Chandra R 2013 Geochemistry of loesspaleosol sediments of Kashmir Valley, India: Provenance and weathering; J. Asian Earth Sci. 66 73-89.

Ahmad Syed Ali and Chaudhry Mohammad Nawaz 2008 A-type granites from the Nagarparkar complex, Pakistan: Geochemistry and origin; Geological Bulletin, Punjab University 43.

Armstrong-Altrin J S 2009 Provenance of sands from Cazones, Acapulco, and Bahía Kino beaches, Mexico; Revista Mexicana de Ciencias Geológicas 26(3) 764-782.

Armstrong-Altrin J S and Verma S P 2005 Critical evaluation of six tectonic setting discrimination diagrams using geochemical data of Neogene sediments from known tectonic settings; Sedim. Geol. 177 115-129.

Armstrong-Altrin J S, Lee Y I, Verma S P and Ramasamy S 2004 Geochemistry of sandstones from the Upper Miocene Kudankulam Formation, southern India: Implications for provenance, weathering, and tectonic setting; J. Sedim. Res. 74(2) 285-296.

Armstrong-Altrin J S, Lee Y I, Kasper-Zubillaga J J, Carranza-Edwards A, Garcia D, Eby G N, Balaram V and Cruz-Ortiz N L 2012 Geochemistry of beach sands along the western Gulf of Mexico, Mexico: Implication for provenance; Chemie der Erde Geochem. 72 345-362.

Armstrong-Altrin J S, Nagarajan Ramasamy, Madhavaraju J, Leticia Rosalez-Hoz A, Lee Yong Il, Balaram V, Cruz-Martinez Adriana and Avila-Ramiirez Gladis 2013 
Geochemistry of the Jurassic and Upper Cretaceous shales from the Molango Region, Hidalgo, eastern Mexico: Implications for source-area weathering, provenance and tectonic setting; Comptes Rendus Geosci. 345 $185-202$.

Armstrong-Altrin J S, Nagarajan R, Lee Y I, KasperZubillaga J J and Cordoba-Saldana L P 2014 Geochemistry of sands along the San Nicolás and San Carlos beaches, Gulf of California, Mexico: Implication for provenance; Turkish J. Earth Sci. 23 533-558.

Armstrong-Altrin J S, Luisa Machain-Castillo Maria, Leticiarosales-Hoz, Arturocarranza-Edwards, SanchezCabeza Joan-Albert and Anacarolinaruiz-Fernández 2015 Provenance and depositional history of continental slope sediments in the southwestern Gulf of Mexico unravelled by geochemical analysis; Cont. Shelf Res. 95 15-26.

Bauluz B, Mayayo M J, Fernandez-Nieto C and GonzalezLopez J M 2000 Geochemistry of Precambrian and Paleozoic siliciclastic rocks from the Iberian Range (NE Spain): Implications for source area weathering, sorting, provenance, and tectonic setting; Chem. Geol. 168 135-150.

Bhatia M R 1983 Plate tectonics and geochemical composition of sandstones; J. Geol. 91 611-627.

Bhatia M R and Crook K A W 1986 Trace element characteristics of greywackes and tectonic discrimination of sedimentary basins; Contrib. Mineral. Petrol. 92 181-193.

Bhawani Singh G, Desai Satish J, Shukla Patel Rajita and Surve Divyesh 2008 Analysis of ichnoguilds and their significance in interpreting ichnological events: A study from Jhuran Formation (Upper Jurassic), western Kachchh; J. Geol. Soc. India 72 458-466.

Bhushan S K and Sahoo P 2010 Geochemistry of clastic sediments from Sargur supra crustals and Bababudan Group, Karnataka: Implications on Archaean Proterozoic boundary; J. Geol. Soc. India 75 829-840.

Biswas S K 1977 Mesozoic rock stratigraphy of Kutch; Quat. J. Geol. Min., Metall. Soc. India 49 1-52.

Biswas S K 1987 Regional tectonic framework, structure and evolution of India, with special reference to western margin basins of India; Tectonophys. 135 307-327.

Biswas S K 2005 A review of structure and tectonics of Kutch basin, western India, with special reference to earthquakes; Curr. Sci. 88 1592-1600.

Biswas S K and Deshpande S V 1983 Geology and hydrocarbon prospects of Kutch, Saurashtra and Narmada basins. In: Petroliferous Basins of India (eds) Bhandari L L, Venkatachala B S, Kumar R, Swamy S N, Garga P and Srivastava D C, Petrol. Asia J. 6(4) 111-126.

Condie K C 1993 Chemical-composition and evolution of the upper continental-crust contrasting results from surface samples and shales; Chem. Geol. 104 1-37.

Condie K C, Dengate J and Cullers R L 1995 Behavior of rare earth elements in paleoweathering profile on granodiorite in the Front Range, Colorado, USA; Geochim. Cosmochim. Acta 59 279-294.

Cox R, Lowe D R and Cullers R L 1995 The influence of sediment recycling and basement composition on evolution of mudrock chemistry in the southwestern United States; Geochim. Cosmochim. Acta 59 2919-2940.

Crook K A W 1974 Lithogenesis and geotectonics: The significance of compositional variation in flysch arenites (greywackes); Soc. Econ. Paleontol. Mineral. 19 304-310.

Cullers R L 1994 The controls on the major and trace element variation of shales, siltstones and sandstones of Pennsylvanian-Permian age from uplifted continental blocks in Colorado to platform sediment in Kansas, USA; Geochim. Cosmochim. Acta 58(22) 4955-4972.

Cullers R L 1995 The controls on the major and trace element evolution of shales, siltstones and sandstones of
Ordovician to Tertiary age in the Wet Mountain region, Colorado, USA; Chem. Geol. 123(1-4) 107-131.

Cullers R L 2000 The geochemistry of shales, siltstones and sandstones of Pennsylvanian-Permian age, Colorado, USA; Implications for provenance and metamorphic studies; Lithos 51 181-203.

Cullers R L 2002 Implications of elemental concentrations for provenance, redox conditions and metamorphic studies of shales and limestones near Pueblo, CO, USA; Chem. Geol. 191 305-327.

Cullers R L, Basu A and Suttner L 1988 Geochemical signature of provenance in sand-size material in soils and stream sediments near the Tobacco Root batholith, Montana, USA; Chem. Geol. 70 335-348.

Cullers R L, Chaudhuri S, Kilbane N and Koch R 1979 Rare earths in size fractions and sedimentary rocks of Pennsylvanian-Permian age from the mid-continent of the USA; Geochim. Cosmochim. Acta 43 1285-1302.

Cullers R L, Barrett T, Carlson R and Robinson B 1987 Rare-earth element and mineralogic changes in Holocene soil and stream sediment: A case study in the Wet Mountains, Colorado, USA; Chem. Geol. 63 275-297.

Cullers R L, Bock B and Guidotti C 1997 Elemental distributions and neodymium isotopic compositions of Silurian meta sediments, western Maine, USA: Redistribution of the rare earth elements; Geochim. Cosmochim. Acta $\mathbf{6 1}$ $1847-1861$.

Deepthi K, Natesan U, Muthulakshmi A L, Ferrer V A, Venugopalan N V P and Narasimhan S V 2013 Geochemical characteristics and depositional environment of Kalpakkam, southeast coast of India; Environ. Earth Sci. $692357-2364$.

Dickinson W R 1985 Interpreting provenance relations from detrital modes of sandstones; In: Provenance of sandstones (ed.) Zuffa G G, D. Reidel., Dordrecht, pp. 333361.

Dickinson W R and Suczek C A 1979 Plate tectonics and sandstone compositions; AAPG Bull. 63 2164-2182.

Dickinson W R, Beard L S, Braken ridge G R, Erjavec J L, Ferguson R C, Inman K F, Knepp R A, Lindberg F A and Ryberg P T 1983 Provenance of North American Phanerozoic sandstones in relation to tectonic setting; Geol. Soc. Am. Bull. $94222-235$.

Drobe M, López de Luchi M G, Steenken A, Frei R, Naumann R, Siegesmund S and Wemmera K 2009 Provenance of the Late Proterozoic to Early Cambrian metaclastic sediments of the Sierra de San Luis (Eastern Sierras Pampeanas) and Cordillera Oriental, Argentina; J. South Am. Earth Sci. 28 239-262.

Gabo J A S, Dimalanta C B, Asio M G S, Queaño K L, Yumul G P Jr and Imai A 2009 Geology and geochemistry of the clastic sequence from northwestern Panay (Philippines): Implications for provenance and geotectonic setting; Tectonophys. 479 111-119.

Herron M M 1988 Geochemical classification of terrigenous sands and shales from core or log data; J. Sedim. Petrol. 58 820-829.

Holland H D 1978 The Chemistry of the Atmosphere and Oceans; New York, Wiley, 351p.

Ingersoll R V and Suczek C A 1979 Petrology and provenance of Neogene sand from Nicobar and Bengal fans, DSDP sites 211 and 218; J. Sedim. Petrol. 49 1217-1228.

Jorge R C G S, Fernandes P, Rodrigues B, Pereira Z and Oliveira J T 2013 Geochemistry and provenance of the Carboniferous Baixo Alentejo Flysch Group, South Portuguese Zone; Sedim. Geol. 284-285 133-148.

Kanjilal S and Prasad S 1992 Geology and stratigraphy of the Callovian-Oxfordian (Jurassic) rocks of Jara Dome, District Kachchh, Gujarat, W. India; J. Indian Acad. Geosci. 35(1) 1-18. 
Krishna Jai 1987 An overview of the Mesozoic stratigraphy of Kachchh and Jaisalmar basins; J. Paleontol. Soc. India 32 136-149.

Kroonenberg S B 1994 Effects of provenance, sorting and weathering on the geochemistry of fluvial sands from different tectonic and climatic environments; Proceedings of 29th International Geological Congress, Part A, pp. 69-81.

Laghari Amanullah 2004 Petrology of the Nagar Parkar granites and associated basic rocks, Thar district, Sindh, Pakistan; PhD Thesis, University of Peshawar, pp. 170-264.

Maslov A V, Gareev E Z and Podkovyrov V N 2010 Upper Riphean and Vendian sandstones of the Bashkirian anticlinorium; Lithol. Miner. Resour. 45(3) 285-301.

McLennan S M 1989 Rare earth elements in sedimentary rocks: Influence of provenance and sedimentary processes; Rev. Mineral. 21 169-200.

McLennan 1993 Weathering and global denudation; J. Geol. $101295-303$.

McLennan S M and Taylor S R 1991 Sedimentary rocks and crustal evolution: Tectonic setting and secular trends; J. Geol. 99 1-21.

McLennan S M, Taylor S R and Eriksson K A 1983 Geochemistry of Archaean shales from the Pilbara Supergroup, Western Australia; Geochim. Cosmochim. Acta 47(7) 1211-1222.

McLennan S M, Hemming S, McDaniel D K and Hanson G N 1993 Geochemical approaches to sedimentation, provenance, and tectonics. In: Processes controlling the composition of clastic sediments (eds) Johnson M J and Basu A, Geol. Soc. Am. Spec. Paper 284 21-40.

Murali A V, Parthasarathy R, Mahadevan T M and Sankar Das M 1983 Trace element characteristics, REE patterns and partition coefficients of zircons from different geological environment - A case study on Indian zircons; Geochim. Cosmochim. Acta 47 2047-2052.

Nesbitt H W and Young G M 1982 Early proterozoic climates and plate motions inferred from major element chemistry of lutites; Nature 299 715-717.

Nesbitt H W and Young G M 1984 Prediction of some weathering trends of plutonic and volcanic rocks based on thermodynamic and kinetic considerations; Geochim. Cosmochim. Acta 48 1523-1534.

Nesbitt H W and Young G M 1989 Formation and diagenesis of weathering profiles; J. Geol. 97 129-147.

Nesbitt H W, Fedo C M and Young G M 1997 Quartz and feldspar stability, steady and non-steady-state weathering, and petrogenesis of siliciclastic sands and muds; J. Geol. 105 173-191.

Norton and Sclater J G 1979 A model for the evolution of the Indian Ocean and the breakup of Gondwanaland; J. Geophys. Res. 84(B12) 6803-6830.

Roy Parijat, Balaram Vysetti, Kumar Anil, Satyanarayanan Manavalan and Rao Thota Gnaneshwar 2007 New REE and trace element data on two kimberlitic reference materials by ICP-MS; Geostand. Geoanal. Res. 31 261-273.

Potter P E 1975 Petrology and chemistry of modern big river sands; J. Geol. 86 423-449.
Potter P E 1986 South America and a few grains of sand, Pt. I. Beach sands; J. Geol. 94(3) 301-319.

Roser B P and Korsch R J 1986 Determination of tectonic setting of sandstone-mudstone suites using $\mathrm{SiO}_{2}$ content and $\mathrm{K}_{2} \mathrm{O} / \mathrm{Na}_{2} \mathrm{O}$ ratio; J. Geol. 94 635-650.

Roser B P and Korsch R J 1988 Provenance signatures of sand-stone--mudstone suites determined using discriminant function analysis of major-element data; Chem. Geol. 67 119-139.

Schwab F L 1975 Framework mineralogy and chemical composition of continental margin type sandstone; J. Geol. 3 487-490.

Selvaraj K and Chen C T A 2006 Moderate chemical weathering of subtropical Taiwan: Constraints from solidphase geochemistry of sediments and sedimentary rocks; J. Geol. 114(1) 101-116.

Singh P 2009 Major, trace and REE geochemistry of the Ganga River sediments: Influence of provenance and sedimentary processes; Chem. Geol. 266 242-255.

Sun Linhua, Gui Herong and Chen Song 2012 Geochemistry of sandstones from the Neoproterozoic Shijia Formation, northern Anhui Province, China: Implications for provenance, weathering and tectonic setting; Chemie der Erde 72 253-260.

Sun L, Gui H and Chen S 2013 Geochemistry of sandstones from the Neoproterozoic Jinshanzhai Formation in northern Anhui Province, China: Provenance, weathering and tectonic setting; Chinese J. Geochem. 32 95-103.

Taylor S R and McLennan S M 1985 The continental Crust: Its Composition and Evolution; Blackwell Scientific, Oxford, 312p.

Verma S P and Armstrong-Altrin J S 2013 New multidimensional diagrams for tectonic discrimination of silica clastic sediments and their application to Pre-Cambrian basins; Chem. Geol. 355 117-180.

Waagen W 1873 Jurassic fauna of Kutch. Memoirs of Geological Survey of India; Paleontologica Indica 1 1-106.

Wani H and Mondal M E A 2010 Petrological and geochemical evidence of the Paleoproterozoic and the MesoNeoproterozoic sedimentary rocks of the Bastar craton, Indian Peninsula: Implications on paleoweathering and Proterozoic crustal evolution; J. Asian Earth Sci. 38 220-232.

Wu W, Zheng H, Xu S, Yang J and Liu W 2013 Trace element geochemistry of riverbed and suspended sediments in the upper Yangtze River; J. Geochem. Expl. 124 67-78.

Wynne A B 1872 Memoir on the geology of Kutch to accompany the map compiled by A B Wynne and F Fidden during the season of 1867-1868 and 1868-1869; Geol. Surv. India Memoir 9(1) 1-293.

Yang Jianghai, Yuansheng D, Cawood Peter A and Yajun $\mathrm{Xu} 2012$ Modal and geochemical compositions of the lower Silurianclastic rocks in north Qilian, NW China: Implications for provenance, chemical weathering, and tectonic setting; J. Sedim. Res. 82 92-103.

Zaigham N A and Mallick K A 2000 Prospect of hydrocarbon associated with fossil-rift structures of the southern Indus basin, Pakistan; Amer. Assoc. Petrol. Geol. Bull. 84(11) $1833-1848$. 